\title{
Approaches to improve the ovulatory response and reproductive performance of ewes introduced to rams during seasonal anestrus
}

\author{
Katherine Mead Jordan \\ West Virginia University
}

Follow this and additional works at: https://researchrepository.wvu.edu/etd

\section{Recommended Citation}

Jordan, Katherine Mead, "Approaches to improve the ovulatory response and reproductive performance of ewes introduced to rams during seasonal anestrus" (2005). Graduate Theses, Dissertations, and Problem Reports. 2202.

https://researchrepository.wvu.edu/etd/2202

This Thesis is protected by copyright and/or related rights. It has been brought to you by the The Research Repository @ WVU with permission from the rights-holder(s). You are free to use this Thesis in any way that is permitted by the copyright and related rights legislation that applies to your use. For other uses you must obtain permission from the rights-holder(s) directly, unless additional rights are indicated by a Creative Commons license in the record and/ or on the work itself. This Thesis has been accepted for inclusion in WVU Graduate Theses, Dissertations, and Problem Reports collection by an authorized administrator of The Research Repository @ WVU. For more information, please contact researchrepository@mail.wvu.edu. 
Approaches to improve the ovulatory response and reproductive performance of ewes introduced to rams during seasonal anestrus

Katherine Mead Jordan

Thesis submitted to the Davis College of Agriculture, Forestry, and Consumer Sciences at West Virginia University in partial fulfillment of the requirements for the degree of

Master of Science in Reproductive Physiology

E. Keith Inskeep, Ph.D., Chair

Marlon Knights, Ph.D.

Paul E. Lewis, Ph.D.

John E. Warren, Ph.D.

Department of Animal and Veterinary Sciences

Morgantown, West Virginia

2005

Keywords: anestrus, season, fertility, ram introduction, gonadotropin-releasing hormone, melatonin

Copyright 2005 Katherine Mead Jordan 


\begin{abstract}
Approaches to improve the ovulatory response and reproductive performance of ewes introduced to rams during seasonal anestrus
\end{abstract}

\author{
Katherine Mead Jordan
}

Three experiments were conducted to test hypotheses relative to the ability of gonadotropin releasing hormone $(\mathrm{GnRH})$ and melatonin to improve responses of anestrous ewes to rams. Treatment with GnRH two days after treatment with progesterone at introduction of rams did not increase ovulation, pregnancy or lambing rates. Treatment with GnRH on days two, seven, or both after introduction of rams, resulted in ovulation, pregnancy, and lambing rates that did not differ. In another trial, $\mathrm{GnRH}$ four days before, or four days before and one day after introduction of rams did not improve a consistently high ovulatory response to introduction of rams without further treatment. Presence of corpora lutea in response to treatment was essential to synchronization of estrus with prostaglandin $F_{2} \alpha$. Treatment for 35 days with a melatonin implant increased the ability of anestrous ewes to respond to introduction of rams, more so in non-lactating than in lactating ewes. 


\section{Table of Contents}

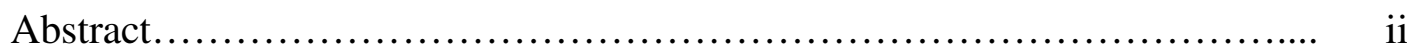

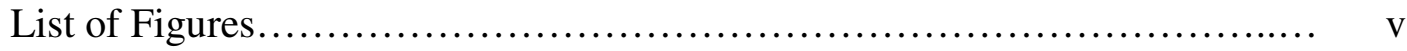

List of Tables.......................................................... vi

Review of Literature................................................. 1

Characterization of seasonal anestrus in the ewe...................... 1

Endocrine basis for seasonal reproduction in the ewe................. 3

Factors affecting length of the breeding season........................ 4

Characterization of lactational anestrus in the ewe...................... 8

Management methods that can induce reproductive

cycles in the anestrous ewe..................................... 11

Introduction of rams

Progestogens and introduction of rams

GnRH and introduction of rams

Manipulation of light

Melatonin treatment

Statement of the Problem.............................................. 28

Introduction........................................................ 30

Materials and Methods................................................ 33

Experiment 1: Effect of treatment with GnRH 2 days after introduction of rams on the reproductive performance of

ewes bred during anestrus.

Experiment 2: Effect of day of treatment with GnRH relative

to introduction of rams on the induction of ovulation and

formation of CL in ewes introduced to rams during anestrus

Experiment 3: Effect of lactational status and pretreatment with melatonin on the ovulatory response and reproductive performance of ewes exposed to rams during anestrus.

Statistical Analysis. 
Results............................................................ 45

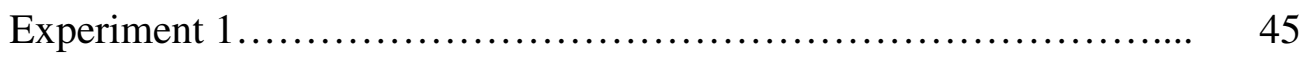

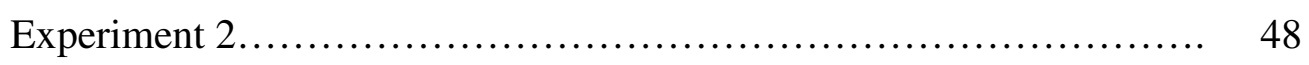

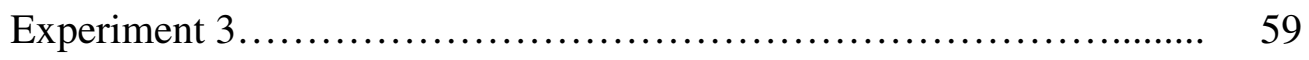

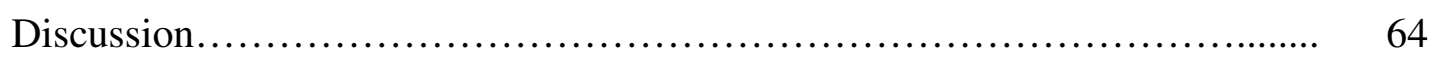

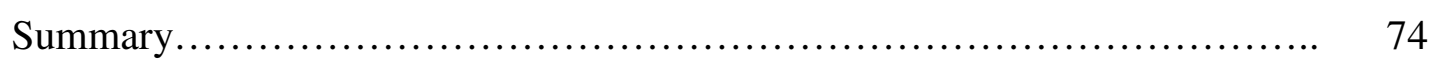

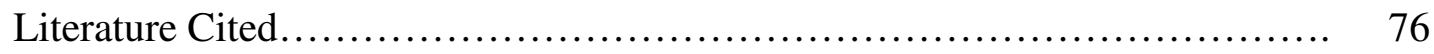

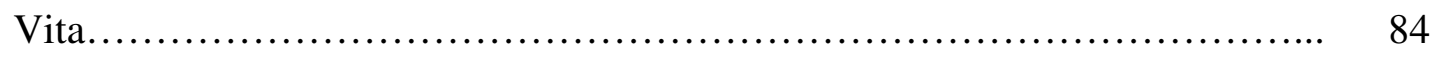




\section{List of Figures}

Figure 1. Timelines for treatment groups in Experiment 1.............................. 35

Figure 2. Timelines for treatment groups in Experiment 2A............................. 37

Figure 3. Timelines for treatment groups in Experiment 2B............................. 39

Figure 4. Timelines for treatment groups in Experiment 3............................... 41

Figure 5. Percentage of ewes marked by rams among ewes in which a CL was detected on day 7 or 14 only, detected on both days, or not detected

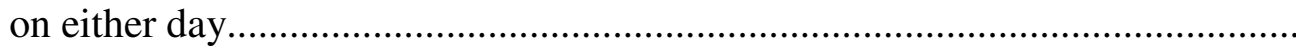

Figure 6. Percentage of ewes pregnant 38 days after induced estrus in ewes in which a CL was detected on day 7 or 14 only, detected on both

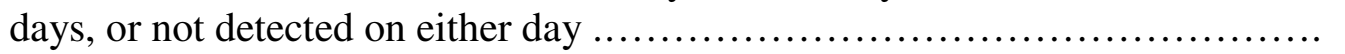

Figure 7. Percentage of ewes pregnant 53 days after induced estrus in ewes in which a CL was detected on day 7 or 14 only, detected on both days,

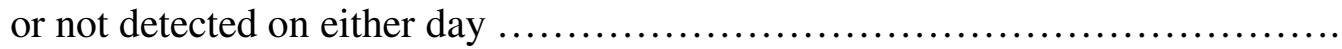

Figure 8. Percentage of ewes lambing overall in ewes in which a CL was detected on day 7 or 14 only, detected on both days, or not detected on either day....

Figure 9. Concentrations of $\mathrm{P}_{4}$ following introduction of rams in ewes that were introduced to rams alone, that were injected with GnRH 4 days before introduction of rams, that were injected with $\mathrm{GnRH} 4$ days before and 1 day after introduction of rams, or that were injected with $\mathrm{P}_{4}$ at the time of introduction of rams.

Figure 10. Percentages of ewes with concentrations of $P_{4}>1 \mathrm{ng} / \mathrm{mL}$ following introduction of rams in ewes that were introduced to rams alone, that were injected with GnRH 4 days before introduction of rams, that were injected with GnRH 4 days before and 1 day after introduction of rams, or that were injected with $\mathrm{P}_{4}$ at the time of introduction of rams......................

Figure 11. Concentrations of melatonin in ewes implanted with melatonin and control ewes on days 0,35 , and 49 after implantation....

Figure 12. Effect of lacatational status, melatonin treatment, and day relative to implantation on percentages of ewes with concentrations of $\mathrm{P}_{4}>1 \mathrm{ng} / \mathrm{ml}$.

Figure 13. Effect of melatonin treatment on percentages of ewes lambing overall. 


\section{List of Tables}

Table 1. Effect of treatment with GnRH on formation of CL, occurrence

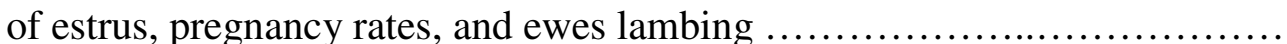

Table 2. Percentages of ewes pregnant and lambing by farm....................

Table 3. Effect of time of treatment with GnRH on formation of CL, follicular development, occurrence of estrus, and fertility ...

Table 4. Effect of time of treatment with GnRH or $\mathrm{P}_{4}$ on estrous response, formation of CL, pregnancy rates, ewes lambing of ewes treated, and days

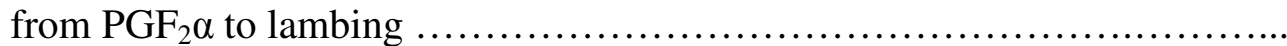

Table 5. Effect of lactational status and melatonin treatment on percentages of ewes lambing overall 


\section{Review of Literature}

\section{Characterization of seasonal anestrus in the ewe}

The ewe is a seasonally polyestrous animal that displays regular estrous activity during a defined breeding season. Reproductive activity in the ewe is under the control of the hypothalamic-pituitary-ovarian axis. During the breeding season, the estrous cycle of the ewe can be divided into follicular and luteal phases. During the follicular phase, the progesterone-induced inhibition of the hypothalamic-pituitary-ovarian axis is released. Increasing secretion of gonadotropin releasing hormone $(\mathrm{GnRH})$ from the hypothalamus drives secretion of luteinizing hormone (LH) from the anterior pituitary gland. The increasing concentrations of LH in the blood stimulate the final stages of growth and maturation of follicles on the ovary and the associated increase in the production of estradiol $\left(E_{2}\right)$. The rise in concentration of $E_{2}$ initiates two important events in the estrous cycle of the ewe. First, the increasing concentration of $E_{2}$ acts on the behavioral centers of the brain to induce estrous behavior. The peak in $E_{2}$ also stimulates a surge in $\mathrm{GnRH} / \mathrm{LH}$ release, which causes ovulation, the release of the oocyte from the follicle. The period of time from the beginning of luteolysis until ovulation is called the follicular phase and normally lasts 2 to 3 days. The duration of estrus in the ewe generally is between 1 to 1.5 days, with an average of 35 hours (McKenzie and Terrill, 1937; Asdell, 1964; Hafez, 1952).

Ovulation marks the transition from the follicular to the luteal phase, which lasts approximately 14 to 15 days. After ovulation, LH remodels the remainder of the follicle wall to form a transitory endocrine gland called the corpus luteum (CL). The CL is the major site for the synthesis and secretion of progesterone $\left(\mathrm{P}_{4}\right)$. Progesterone suppresses 
the tonic release of $\mathrm{GnRH}$ and $\mathrm{LH}$, and in so doing, indirectly suppresses ovulation and estrous behavior. Progesterone also plays a major role in preparation of the reproductive tract for pregnancy and is the major hormone that supports and maintains gestation. If conception does not occur, prostaglandin $\mathrm{F}_{2} \alpha\left(\mathrm{PGF}_{2} \alpha\right)$, produced by the uterus, initiates the regression of $C L$, halting the production of $\mathrm{P}_{4}$. Decreasing $\mathrm{P}_{4}$ signals the end of the luteal phase and the start of the new follicular phase. However, if an embryo is present in the uterus, the $\mathrm{CL}$ does not regress, but is maintained and continues to secrete $\mathrm{P}_{4}$ throughout the pregnancy (reviewed by Bazer and First, 1983).

The ewe has a pattern of seasonal reproduction with maximum reproductive activity associated with short-day photoperiods. Accordingly, the percentage of ewes displaying estrus is greater during the late summer, fall and early winter months (McKenzie and Terrill, 1937; Hulet et al., 1974). Nearly all Targhee, Hampshire, Rambouillet, Suffolk, Polled Dorset, and Columbia ewes displayed estrus during September through March in Wisconsin, after which the percentage of ewes displaying estrus declined from April through June (Mallampatti et al., 1971; Lax et al., 1979), then gradually increased as the breeding season approached once again. Ovulation rate follows an annual pattern similar to that of estrous activity with the number of ovulations being highest during the breeding season and lowest during the non-breeding season (Mallampati et al., 1971; Hulet et al., 1974). The non-breeding season, also referred to as anestrus or the anestrous period, can therefore be defined as a period of low to nonexistent ovulatory and estrous activity.

The peak in breeding activity of the ewe occurs from September to November in the Northern Hemisphere and is reflected in a subsequent peak in lambing activity from 
February to April. The breeding and lambing patterns are reflected in seasonal availability of lamb and fluctuations in price. Inducing ewes to breed out-of-season is therefore aimed at providing a more consistent supply and obtaining premium prices for lambs.

\section{Endocrine basis for seasonal reproduction in the ewe}

The changes in reproductive activity observed during anestrus are consequences of changes at the hypothalamic-pituitary axis, specifically a decrease in the frequency of secretion of GnRH from the hypothalamus and a resultant decrease in secretion of $\mathrm{LH}$ from the pituitary. This decrease in frequency of secretion of GnRH is attributed to an increase in the sensitivity of the hypothalamus to the negative feedback effects of $E_{2}$ (Legan et al., 1977). Karsch and colleagues (1993) found that during anestrus, $E_{2}$ at physiological concentrations inhibited LH secretion through suppression of the frequency of GnRH pulses. However, during the breeding season, the same concentration of $\mathrm{E}_{2}$ was not effective in inhibiting LH pulse frequency (Karsch et al., 1993). Therefore, the main endocrine event responsible for the anestrous period in the ewe is the increase in the negative feedback effect of $\mathrm{E}_{2}$ on pulsatile secretion of GnRH and $\mathrm{LH}$.

Although changes in temperature can be associated with changes in the reproductive activity of the ewe, it is now known that the dominant environmental signal that cues and synchronizes the breeding season in sheep is photoperiod (Hafez, 1952; Wodzicka-Tomasezewksa et al., 1967; Karsch et al., 1984). Marshall (1937) demonstrated that the annual reproductive cycle of ewes shifted in accordance with the new photoperiod when ewes were transferred across the equator. 
Photoperiodic information is conveyed through several neural relays from the retina to the pineal gland, where the light signal is translated into a hormonal signal, melatonin. The mechanism by which daylength is perceived was reviewed by Karsch et al. (1984). Briefly, a retinohypothalamic tract projects from photoreceptors in the retina to the suprachiasmatic nucleus, and then to the paraventricular nucleus and the superior cervical ganglion, which in turn innervates the pineal gland. The pineal gland responds to darkness with an increase in melatonin secretion and to light with a decrease in secretion. This is reflected in high concentrations of melatonin during the night and low concentrations during the day. These differences in the pattern of melatonin secretion translate the photoperiodic signal to the neuroendocrine axis. This pathway was elucidated by studies that involved lesioning parts of the neural relay system that link the retina to the pineal gland. Blinded ewes exhibited estrous and anestrous periods, but these were no longer synchronous with the normal seasonal patterns in sighted ewes (Karsch et al., 1984). There is evidence that melatonin may be a useful tool in advancing the onset of the breeding season, which will be discussed further in a section of this review.

\section{Factors affecting length of the breeding season}

In addition to photoperiodic signals, many other factors, including breed and its geographic origin, individual genetics, age, and nutritional and lactational status, influence the duration and timing of the breeding season in ewes. These factors were discussed in detail in reviews by Whisnant and Inskeep (1992) and Knights (2001), and will be summarized briefly. The effects of lactation on seasonal reproduction will be 
discussed in detail in subsequent sections. It is interesting to note that data pertaining to the length of the breeding season have been reported in a variety of ways including the number of estrous periods per year, the proportion of ewes showing estrus or ovulating each month, the duration of the season in weeks, and the number of estrous periods in the season.

\section{Breeds and their geographic origins}

Breeds of a tropical origin, especially those from the Mediterranean region, and those with Merino ancestry have breeding seasons of longer durations than those breeds originating from temperate and higher latitudes (Whisnant and Inskeep, 1992). Two exceptions to this general rule are the Dorset and Finnsheep breeds, which have extended breeding seasons despite their origins in temperate latitudes. Breeds with extended breeding seasons include the Dorset, Rambouillet, Finnsheep, and crosses with and among these breeds. Those breeds with intermediate-length breeding seasons include the Corriedale, Columbia, and Targhee, while the Suffolk, Hampshire, Oxford, Southdown, Shropshire, and Cheviot are breeds with short seasons. However, data from studies comparing the length of the breeding seasons of multiple breeds have been confounded by the fact that not all breeds of ewes have high proportions exhibiting behavioral estrus in association with ovulation. For example, Quirke et al. (1988) noted that Rambouillet ewes had a tendency to ovulate without estrus at the beginning and end of the breeding season. Additionally, there is great variation in the duration of the breeding season among locations and years and within breeds. These facts are further confounded by factors such as individual genetics, time since last lambing, nutritional and lactational status, age, and the presence of rams. Marshall (1937) observed that the latitude in which 
the study is conducted can have a large impact on the duration of the breeding season. Researchers and producers alike are able to take advantage of breed differences in the degree of seasonality to improve the ability of ewes to breed out-of-season (Notter et al., 1992).

\section{$\underline{\text { Genetic Selection }}$}

Heterosis, or hybrid vigor, is important for many reproductive traits and this appears to hold true for length of breeding season. In studies reviewed by Notter (1992), DLS sheep, which are a mix of Dorset, Leicester and Suffolk stock, had a longer breeding season than any of the component purebreds. Likewise, the breeding season of crosses of the Dorset, Rambouillet, and Finnsheep breeds averaged 9 days longer than those of the parent purebreds (Quirke et al., 1988). The duration of first breeding season of Finnsheep x Dorset ewe lambs was 131 days, compared to 127 days in Finnsheep and 87 days in Dorsets (Quirke et al., 1985). Based on these results, heterosis may be beneficial to selection for long breeding seasons; studies on other traits associated with out-ofseason breeding, such as conception rates in various seasons, have been inconclusive.

Few studies have assessed objectively the opportunities for within-breed genetic improvement in traits associated with out-of-season breeding. Although several experimental populations with desirable out-of-season breeding characteristics have been developed through a combination of crossbreeding and selection, it has generally not been possible to separate effects of initial breed composition and non-genetic adaptations to the imposed management from the effects of selection. Furthermore, heritability estimates for seasonal reproductive traits ranged from .03 to .32 , adding another level of complexity to improving out-of-season breeding traits through selection (Al-Shorepy and 
Notter, 1996). Results of selection experiments indicate that some level of genetic control of the seasonality of reproduction exists, but few controlled experiments appear to have resulted in large, documentable changes in the seasonal breeding pattern within breeds.

$\underline{\text { Age }}$

The breeding season is shorter in ewe lambs than in mature ewes (Cole and Miller, 1935; Hafez, 1952). Dyrmundsson (1973) concluded that the first breeding season of ewe lambs is shorter because it begins later and ends earlier. Although genetic selection extended the breeding season in mature ewes, these improvements were not achieved in ewe lambs or yearlings (Notter, 1992).

\section{$\underline{\text { Nutrition }}$}

The precise mechanisms by which nutrition influences reproduction are not well understood. However, it is clear that body condition directly affects hypothalamic activity and GnRH secretion and that effects on reproductive performance are mediated by way of changes in ovarian hormones or in hypothalamic-pituitary sensitivity to ovarian hormones (Rhind et al., 1989). Conception and pregnancy rates generally are depressed when ewes are kept on a poor plane of nutrition before mating (Coop, 1966; Gordon, 1997). The percentage of ewes responding to introduction of rams with ovulation and the percentage of ewes having spontaneous ovulations the following spring were greater in ewes on a high than a low plane of nutrition during autumn and early winter (Oldham and Fisher, 1992). When a poor plane of nutrition is superimposed on lactation during the time of rebreeding, severe negative effects on reproduction may be observed. 
It has been thought for many years by commercial sheep farmers that the flushing of ewes prior to the start of the breeding season may have a profound positive influence on the lamb crop produced by those ewes the following spring. Hulet et al. (1962) found $8-16 \%$ increases in twinning rates when range ewes were supplemented with oats or lucerne pellets for 17 days prior to introduction of rams. West et al. (1991) observed an increase in ovulation rates when ewes were fed alfalfa pellets equivalent to $150 \%$ NRC maintenance energy requirements for 3 weeks prior to the breeding season. The effects of flushing may be attributed to increased liver function which results in an increase in metabolism of $\mathrm{P}_{4}$ due to increased secretion of liver enzymes and hepatic blood flow.

\section{Characterization of lactational anestrus in the ewe}

The response to estrous induction procedures is generally lower in lactating than in non-lactating ewes during anestrus. Conception and pregnancy rates generally are depressed when ewes are mated while lactating during the anestrous season. Therefore, lactation creates another level of complexity in relation to expectations for reproductive performance of the ewe in different seasons. The effects of lactation on various lambingrelated variables were reviewed by Cognie and colleagues (1975). In contrast to results observed in cows, the restoration of the uterus after lambing took longer in lactating than in non-lactating ewes (Foote et al., 1971). The elimination of cellular debris and the return to normal uterine weight took longer in spring than in autumn and after lambing in the spring, more lactating than non-lactating ewes still had cellular debris in the uterus at 24 days postpartum (30 vs. 0\%; Cognie et al., 1975). Greater dosages of equine chorionic gonadotropin (eCG) were required to induce ovulation in lactating than in non- 
lactating ewes. The number of ovulations was more variable and ovulations were spread over a longer period in lactating than in non-lactating ewes (Cognie et al., 1975). A high proportion of uterine contractions originating near the oviducts and moving toward the cervix, rather than the other direction, was cited as one possible cause for poor conception rates in ewes bred during the early postpartum period (Kiesling et al., 2000). A more likely explanation is that the fertility problem begins even before mating, as lactating ewes have reduced ovulatory responses and lower ovulation rates.

Lactating ewes have longer intervals to first estrus and conception than nonlactating ewes (Whiteman et al., 1972; Pope et al., 1989). In fall-lambing ewes, the percentage of ewes that showed estrous behavior by day 67 postpartum was greater in non-lactating than lactating ewes (89 vs. 33\%; Call et al., 1976). When seasonal anestrus is combined with lactation, a significant block to successful pregnancy ensues.

There are numerous physiological reasons for lowered fertility in lactating anestrous ewes. During lactation, serum concentrations of prolactin are elevated and are related inversely to the concentrations of $\mathrm{LH}$ and follicle stimulating hormone (FSH) in serum. However, in ovariectomized ewes, elevated concentrations of prolactin in serum did not directly inhibit the pituitary's ability to respond to GnRH (Moss et al., 1980). Recent findings using the postpartum suckled cow may aid in understanding the related endocrine events in the postpartum ewe. Mean concentrations of LH and the frequency and amplitude of episodic LH peaks are lower in suckling dairy cows (Williams et al., 1982). Whether suckling-mediated events decrease basal LH secretion by interacting at the hypothalamic level, pituitary level, or both, is still unclear. Beef cows suckling a calf released less $\mathrm{LH}$ in response to $\mathrm{GnRH}$ on day 5 postpartum than cows not suckling a calf. 
Further, GnRH-induced LH release was lower in pituitary explants from dairy cows suckling calves at day 14 postpartum compared to explants from cows that were not suckling calves. The authors suggested that pituitary gonadotrophs of early postpartum suckled cows were either somewhat refractory to GnRH stimulation or contained a smaller readily releasable pool of LH than those of non-suckled cows. Separately, GnRH and $E_{2}$ successfully induced release of LH in suckled cows between 17 and 60 days postpartum. The characteristics of these releases were similar to those seen in ovariectomized heifers and milked dairy cows at 2 weeks postpartum. The authors concluded that adequate amounts of releasable LH are available early in the postpartum period of suckled cows. Therefore, normal synthesis and storage of pituitary LH may occur even if the frequency and amplitude of GnRH release are inadequate to sustain normal tonic LH secretion.

In sheep, Moss et al. (1980) reported that the resumption of estrous behavior following parturition was associated with increasing pituitary stores of LH and FSH, but not with altered hypothalamic content of $\mathrm{GnRH}$ or changes in the pituitary response to GnRH. Similar to the findings of Williams and colleagues (1982), they failed to demonstrate any effect of suckling on readily releasable pools of LH between 1 and 30 days postpartum.

Adding to the complexity of the effects of lactation on reproduction is the fact that there appear to be interactions between lactation and the season in which it occurs. Ford (1979) found that serum concentrations of LH increased between days 10 and 30 postpartum in ovariectomized ewes. Ewes that lambed in the fall and did not nurse any lambs had higher concentrations of LH than ewes that nursed one or two lambs. Further, 
8 days after ovariectomy, concentrations of LH were higher in ewes that lambed in the fall than in ewes that lambed in the spring (Ford, 1979).

\section{Management methods that can induce reproductive cycles in the anestrous ewe}

Several methods of inducing reproductive cycles in the anestrous ewe have been researched extensively and reviewed (Knights, 2001). Some of the approaches investigated include introduction of rams, treatment with $\mathrm{P}_{4}$ in conjunction with introduction of rams, treatment with $\mathrm{GnRH}$ in conjunction with introduction of rams, manipulation of light, and treatment with melatonin.

\section{Introduction of rams}

One method used to achieve breeding activity during the non-breeding season is to join previously isolated anestrous ewes with rams before the start of the normal breeding season. Numerous studies have shown that the introduction of rams to seasonally or lactationally anovulatory ewes results in ovulation. Underwood and colleagues (1944) and Schinckel (1954) showed that anestrus in Merino ewes could be interrupted by introduction of rams due to induced ovulation. This method is commonly referred to as the "ram effect" or "male effect". In order to get a reproductive response to introduction of rams, it is common practice to isolate the ewes from rams (including sight, sound, and smell) for a period of time before introduction. There is recent evidence, however, that isolation may not be essential if novel rams are used. Cushwa and colleagues (1992) found introduction of novel rams evoked similar responses from 
ewes that were isolated from rams (housed $1.5 \mathrm{~km}$ away) and ewes that were adjacent to rams (either in pens $15 \mathrm{~m}$ away or in adjacent pastures separated only by a fence).

As discussed previously, release of GnRH from the hypothalamus controls release of LH from the anterior pituitary. Therefore, the pattern of release of LH is generally similar to that of GnRH (Clarke and Cummins, 1982). In anestrous ewes, GnRH and LH pulses occur very infrequently compared to pulses in ewes during the breeding season. This decrease in frequency is due to the increased sensitivity of the hypothalamus to the negative feedback effects of $E_{2}$ (Legan et al., 1977). From initial studies, it was suggested that introduction of rams might directly cause the preovulatory LH surge (Knight et al., 1978), however it is now apparent that the first effect of introduction of rams is an increase in tonic LH secretion, causing the onset of a typical follicular phase (Martin et al., 1983). The increase in LH pulse frequency drives follicular development, resulting in a rise in the circulating concentrations of $E_{2}$ (Goodman, 1994). The observation by Martin and colleagues (1983) that the ram-induced increases in LH pulse frequency do not occur in the absence of ovaries supports this hypothesis. The increase in circulating concentrations of $\mathrm{E}_{2}$ has two effects: in the first 2 to12 hours, it reduces concentrations of FSH and amplitude of LH pulses; in 12 to 48 hours, it induces preovulatory surges of both LH and FSH. The LH surge induces ovulation and the formation of CL (Martin et al., 1986).

In anestrous ewes, $E_{2}$ is capable of inducing an LH surge within as little as 6 to 8 hours after treatment, but the average is nearer 18 hours. As noted by Knights (2001), responsiveness of follicles to gonadotropic stimulation is reduced in anestrous ewes, which may limit the synthesis of $E_{2}$ that can be attributed to ram-induced increases in the 
synthesis of gonadotropins. Additionally, Martin and colleagues (1986) observed that the period from introduction of rams to the LH surge (approximately 36 hours) is shorter than the normal follicular phase in cycling ewes. The authors proposed that these early surges are a result of exaggerated stimulation of tonic LH secretion by introduction of rams. It is possible that an increase in the sensitivity of the $\mathrm{LH}$ surge mechanism to $\mathrm{E}_{2}$ rather than an actual increase in the concentration of $\mathrm{E}_{2}$ might contribute to triggering the early $\mathrm{LH}$ surges observed in some animals.

The precise mechanism through which the introduction of novel rams results in increased secretion of LH in anestrous ewes is not clearly understood. Because the raminduced increase in pulse frequency of LH is observed in ovariectomized, $\mathrm{E}_{2}$-treated, but not control ewes, disruption of the $E_{2}$ negative feedback system seems a likely explanation (Martin et al., 1983). Estrogen negative feedback effects are probably mediated by catecholaminergic neurons (Havern et al., 1994). The suppression of these catecholaminergic neuronal systems might explain why the ram effect induces an increase in tonic LH secretion. As summarized by Knights (2001), the introduction of rams induces a follicular phase in anestrous ewes by blunting the actions of long photoperiod, allowing ewes to revert transiently to the reproductive condition found during the breeding season.

Few data exist on the pattern of growth and development of follicles following introduction of rams to anestrous ewes. An increase in the number of small, large, and total follicles has been observed during the first 40 hours after introduction of rams (Atkinson and Williamson, 1985). Most ewes ovulate within 50 hours after introduction of rams (Martin et al., 1986). Martin and colleagues (1986) reported increased ovulation 
rates in seasonally anestrous ewes introduced to rams compared to rates of ewes that spontaneously ovulated during the same time. However, results from studies investigating the ovulation rates in response to introduction of rams are inconsistent, possibly due to differences in nutritional status and the method of selection of experimental animals.

Because of the lack of exposure to $\mathrm{P}_{4}$ prior to the ram-induced increases in $\mathrm{E}_{2}$, the first ovulation is not associated with behavioral estrus. It should be noted that breed differences might affect the proportion of ewes showing estrus in conjunction with ovulation at the onset of the breeding season (Quirke et al., 1988). Oldham and Martin (1978) reported that the CL resulting from the first ram-induced ovulation might experience a normal lifespan or be short-lived, regressing prematurely. Ewes with a normal CL will ovulate in conjunction with estrous behavior 17 days later. Corpora lutea that are short-lived regress 5 to 6 days after ovulation and are usually followed by another ovulation without estrus. The length of the second luteal phase usually is normal with estrus and ovulation occurring about 17 days later (Oldham and Martin, 1978). Thus, the estrous activity of the flock is spread over 10 days with two peaks; the first around day 18 and the second around day 24 after rams are introduced.

Knight and Lynch (1980) demonstrated that the scent from the male was the most important sensory cue in inducing ovulation in anestrous ewes. They found that the wool and wax of rams contained odoriferous substances, pheromones, which stimulated $48 \%$ of a group of ewes to ovulate within 5 days of introduction, a response similar to that in ewes in contact with rams. Surprisingly, ram urine was not a major source of the pheromone (Knight and Lynch, 1980). As reviewed by Knights (2001), there are two 
olfactory systems, the main and vomeronasal systems, which conduct sensory inputs to the central nervous system. In the ewe, the main olfactory system alone is capable of conducting the pheromonal stimuli to the central nervous system. Indeed, vomeronasal cauterization and nerve section that spared the main olfactory system did not inhibit the increased LH response of ewes exposed to the odor of males (Cohen-Tannoudji et al., 1989). The induction of increased secretion of LH by the fleece of rams alone supports the concept that visual and physical components of perception of the ram are not essential (Knight and Lynch, 1980). Once the bulbs of the main olfactory system sense a pheromonal stimulus, the message is sent on to the olfactory cortex, from which efferent fibers branch out, innervating the hypothalamus via the amygdala and fornix (Knights, 2001). Thus, the pheromonal stimulus can be mediated through the hypothalamus to stimulate the secretion of $\mathrm{GnRH}$.

There is a wide range of variation in responses of ewes to introduction of rams. The factors affecting magnitude of the response were reviewed by Oldham and Fisher (1992) and Knights (2001). Isolation of ewes from the rams for at least 1 month prior to introduction is the generally accepted practice (Oldham and Fisher, 1992). These authors suggested that a process of habituation occurs, whereby rams lose their ability to stimulate increased secretion of LH from ewes after joining (Oldham and Fisher, 1992). If habituation occurs after the first induced estrus, then ewes become anovulatory again before ever displaying estrus (Pearce et al., 1985). The stage or depth of anestrus, as reflected by the percentage of spontaneously ovulating ewes in the flock, also influences the response to introduction of rams. Oldham and Fisher (1992) showed that the percentage of ewes ovulating in response to introduction of rams was positively 
correlated with the proportion of the flock ovulating spontaneously at the time. Additionally, the length of the postpartum interval at introduction, breed differences of both the rams and ewes, sexual activity level of the rams, and nutritional status of the ewes, as discussed previously, affect the magnitude of the response of anestrous ewes to introduction of rams.

\section{$\underline{\text { Progestogens and introduction of rams }}$}

Progesterone was first used to synchronize estrus over five and a half decades ago (Dutt and Casida, 1948), and fertile estrus was induced in anestrous ewes with progesterone and equine chorionic gonadotropin (Dutt, 1953). Progestogens are important to many processes that make out-of-season breeding possible, including display of behavioral estrus and the maintenance of the first ram-induced CL. A multitude of treatment combinations has been developed using progestogens and gonadotropins at different dosages and times. A limitation to the use of progesterone in out-of-season breeding approaches is that it is not readily available to sheep producers.

As discussed earlier, the first ram-induced ovulation in anestrous ewes is not accompanied by estrous behavior. However, at subsequent ovulatory events, estrus is exhibited. In early studies, evidences was obtained that $\mathrm{P}_{4}$ blocks the initiatory effects of $\mathrm{E}_{2}$ on estrus (Dutt and Casida, 1948). The stimulatory roles of $\mathrm{P}_{4}$ pre-treatment on sexual behavior have since been demonstrated and reviewed (Knights, 2001). The occurrence of estrous behavior in conjunction with ovulation in response to introduction of rams during anestrus is dependent on the presence and age of functional CL on the ovary at the time of treatment (Robinson, 1950). In a study on maiden ewes during seasonal anestrus, 
Robinson (1955) observed estrous behavior in all $\mathrm{P}_{4}$ pre-treated ewes receiving $\mathrm{E}_{2}$ or $\mathrm{E}_{2}$ and eCG. Ewes receiving similar dosages of $\mathrm{E}_{2}$ and/or eCG but without $\mathrm{P}_{4}$ pre-treatment did not show behavioral estrus. Ewes expressed estrus in response to $E_{2}$ even though they were last treated with $\mathrm{P}_{4}$ eight days previously (Fabre-Nys and Martin, 1991). When $\mathrm{P}_{4}$ was present at the time of $\mathrm{E}_{2}$ treatment, progesterone inhibited the stimulatory effect of $\mathrm{E}_{2}$, but this effect disappeared as soon as the $\mathrm{P}_{4}$ was withdrawn. Thus it appears that it is not necessary or desirable for $\mathrm{P}_{4}$ to be present immediately prior to administration of $\mathrm{E}_{2}$, but rather there is a requirement for some pre-exposure to $\mathrm{P}_{4}$.

The data on duration of progestogen treatment to allow ewes to show behavioral estrus at the first ram-induced ovulation indicate a minimum requirement of 5 to 6 days to allow for adequate sensitivity to be developed in the behavioral brain centers to the amounts of $E_{2}$ secreted as a result of gonadotropin treatment and or introduction of rams (Knights, 2001).

Corpora lutea from the ovulation resulting from introduction of rams or administration of $\mathrm{GnRH}$ or $\mathrm{LH}$ to anestrous ewes were short-lived in at least 50\% of all ewes (Knights, 2001). Treatment with $\mathrm{P}_{4}$ prior to the induction of ovulation prevented the premature regression of CL. The $\mathrm{P}_{4}$ pre-treatment may be given in the form of a long-term regimen beginning 10 to 14 days before ovulation (McLeod, et al., 1982), or in the form of a single intra muscular injection at the time of introduction of rams or treatment with GnRH, LH, or FSH (Oldham et al., 1985; Ahmad et al., 1996). Each of these methods of administration elevated serum concentrations of $\mathrm{P}_{4}$ to greater than 1 $\mathrm{ng} / \mathrm{mL}$ for at least 30 hours, which appears to be the minimal duration of $\mathrm{P}_{4}$ exposure needed for normal luteal lifespan (Knights, 2001). In conclusion, a single injection of $\mathrm{P}_{4}$ 
at the time of introduction of rams did not affect the proportion of ewes that ovulated or displayed estrus but ensured that all CL that resulted from introduction of rams persisted for the period of a normal estrous cycle (Oldham and Fisher, 1992; Pearce et al., 1985).

Earlier studies led to the suggestion that inadequate luteal function in anestrous ewes induced to ovulate might be due to poor response to the LH surge, probably due to problems in the final maturational stages of the ovulatory follicle (Hunter et al., 1986). However, Southee and colleagues (1988) showed that uterine-derived $\mathrm{PGF}_{2} \alpha$ was responsible for the premature regression of $\mathrm{CL}$ induced in anestrous ewes without $\mathrm{P}_{4}$ pretreatment. Hunter and colleagues (1989) also concluded that premature release of $\mathrm{PGF}_{2} \alpha$ was the cause of early luteal regression. There is evidence that $\mathrm{P}_{4}$ pre-treatment might protect CL from early regression by causing an early rise in $\mathrm{PGF}_{2} \alpha$ prior to ovulation or before CL become susceptible to the luteolytic effects of $\mathrm{PGF}_{2} \alpha$ (Knights, 2001).

The types and relative efficiencies of progestogens used for the control of the estrous cycle during the breeding season and induction of estrus in non-cycling ewes were reviewed by Knights (2001). Compounds studied include progesterone, SC-9880 (fluorogestone acetate), medroxy progesterone acetate (MAP), SC-9022, SC-21009 (Norgestomet), and melengestrol acetate (MGA). Although potencies and dosages vary markedly, there seems to be little difference in the efficacy of the various progestogens to induce fertile estrus in anestrous ewes. The choice of a particular progestogen may therefore be related more to other factors such as availability, ease of use, and approval by regulatory agencies.

Knights (2001) reviewed the methods of progestogen administration, including intramuscular injection, progestogen-impregnated intravaginal or subcutaneous pessaries, 
orally active feed additives, ear implants, and controlled internal drug release dispensers (CIDRs). As with the particular progestogen used, there are limited differences in the efficacy of the various methods of administration, with the exception that intake can vary when the hormone is delivered in feed or drinking water.

A variable and generally lower conception rate relative to cycling ewes has been associated with synchronization of estrus with progestogens (Dutt and Casida, 1948). Knights (2001) concluded from the literature that the threshold dosage of progestogen beyond which fertility is compromised is lower for induction of fertile estrus in anestrous ewes than for synchronization of estrus during the breeding season.

\section{$\underline{\mathrm{GnRH}}$ and introduction of rams}

Gonadotropin releasing hormone is a decapeptide hormone synthesized by neurons in the hypothalamus and secreted into the capillary bed of the median eminence (Gilbert, 1999). It stimulates secretion of LH and FSH from the anterior lobe of the pituitary. Slight alterations in the native structure of GnRH have led to the production of potent analogues available for therapeutic purposes. These GnRH analogues are more available to sheep producers than progesterone and may be able to replace progesterone in out-of-season breeding approaches, although they elicit different physiological responses. Several GnRH products that are commercially available include: Cystorelin (Merial), Factrel (Fort Dodge Laboratories), OvaCyst (Vedco), and Fertagyl (Intervet). Although their potencies differ on a weight basis, the products are biologically equivalent at the recommended dosages of $2 \mathrm{~mL}$ of Cystorelin, Factrel, or Fertagyl (Lamb, 2002). 
Many attempts have been made to incorporate $\mathrm{GnRH}$ into reproductive management protocols in cattle. These studies may provide insight into the possible uses of GnRH in anestrous ewes. The responses of postpartum cows to treatment with GnRH are conflicting. Stevenson and Call (1988) treated Holstein dairy cows with a single

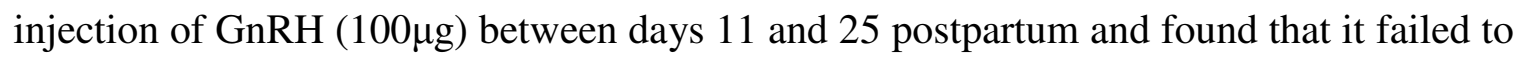
improve reproductive performance. In contrast, Benmrad and Stevenson (1986) found that treatment of postpartum Holstein dairy cows with GnRH $(200 \mu \mathrm{g})$ reduced intervals to first ovulation and first detected estrus and increased the proportion of cows with three or more ovulations before first service. Treatment with GnRH at or near the time of insemination has yielded little improvement of pregnancy rate. Studies on repeat breeder animals have given mixed results. Stevenson and colleagues (1990) found that GnRH $(100 \mu \mathrm{g})$ administered at the time of insemination in dairy cattle increased pregnancy rates of repeat breeders. Chenault (1990) found that administration of 25, 50, 75, or 100 $\mu \mathrm{g}$ of one of two GnRH agonists did not improve conception rates in lactating dairy cows. Single or repeated injections of GnRH during diestrus delayed CL regression. Theoretically, this may allow the developing embryo more time to signal its presence to the uterus and prevent luteolysis. GnRH is a well-established treatment for ovarian cysts in cattle, mediated by its stimulation of LH release.

Injection of GnRH during the luteal phase in some cows or in anestrous cows synchronized follicular development by inducing ovulation of a mature follicle or by causing luteinization or atresia of the existing dominant follicle. In either case, recruitment of a new cohort of follicles is necessary before ovulation in relation to estrus can occur. Treatment with GnRH simultaneously with a luteolytic dose of $\mathrm{PGF}_{2} \alpha$ 
disrupted follicular dynamics and induced premature ovulation or delayed normal return to estrus (Stevens et al., 1993). In 1993, Thatcher and colleagues reported that if GnRH was administered 7 days before $\mathrm{PGF}_{2} \alpha$, enhanced synchrony of estrus and ovulation could be obtained.

Multiple programs for synchronized breeding in cattle have been developed with varying degrees of success (reviewed by Lamb, 2002). The "Ovsynch" protocol was developed for lactating dairy cows that are not exhibiting estrus and involves two injections of $\mathrm{GnRH}$; one injection 7 days before $\mathrm{PGF}_{2} \alpha$ and a second injection 48 hours after $\mathrm{PGF}_{2} \alpha$, followed by timed breeding 24 hours later. The "Select Synch" protocol involves an injection of GnRH 7 days before $\mathrm{PGF}_{2} \alpha$, followed by heat detection and artificial insemination and initiates estrous cycles in anestrous postpartum cows. The "CO-Synch" protocol is similar to "Ovsynch" except that it reduces the number of times the cattle must be handled, because the second injection of GnRH is administered at the time of artificial insemination. The "Hybrid Synch" protocol is a combination of "Select Synch" and "CO-Synch" and involves two injections of GnRH; one injection 7 days before $\mathrm{PGF}_{2} \alpha$, heat detection and artificial insemination following $\mathrm{PGF}_{2} \alpha$, and a second injection of GnRH 54 hours after $\mathrm{PGF}_{2} \alpha$ in conjunction with artificial insemination. In studies reviewed by Lamb (2002), pregnancy rates ranged from 52 to $61 \%$ with "Ovsynch" and 33 to 54\% with "Co-Synch", while conception rates ranged from 66 to 77\% with "Select Synch" and 34 to 79\% with "'Hybrid Synch", resulting in pregnancy rates of 38 to $71 \%$ and 34 to $71 \%$, respectively.

While early studies demonstrated the success of GnRH-based protocols in synchronizing and inducing estrus in cycling and anestrous cattle, fewer studies have 
examined the use of GnRH in anestrous ewes. GnRH based out-of-season breeding protocols are aimed at providing a source of $\mathrm{P}_{4}$ by inducing ovulation or luteinization of follicles. This period of exposure to $\mathrm{P}_{4}$ is essential for preventing the premature regression of any subsequent CL and in the display of behavioral estrus, as discussed previously. Crighton and colleagues (1973) and Haresign and colleagues (1975) found that administration of $150 \mu \mathrm{g} \mathrm{GnRH}$ to anestrous ewes resulted in a rise in plasma $\mathrm{LH}$ that peaked at 110 minutes after treatment and resulted in ovarian changes characteristic of ovulation having occurred (i.e. luteal tissue) by 3 to 4 days after treatment. It should be noted, however, that a single treatment with $\mathrm{GnRH}$ did not result in normal luteal function, indicating the need for $\mathrm{P}_{4}$ pre-treatment to ensure normal luteal lifespan. Bartlewski et al. (2001) confirmed this observation in a study on the ovarian responses in GnRH-treated anestrous ewes. The authors treated anestrous ewes with $125 \mu \mathrm{g} \mathrm{GnRH}$ at 2-hour intervals for 24 hours, and found that $83 \%$ of ewes ovulated; $45 \%$ of those that ovulated experienced a short-lived CL (Bartlewski et al., 2001).

Many studies differed in timing, dosage, and method of treatment with GnRH. Lopez-Sebastian and colleagues (1984) found that a single injection of $50 \mu \mathrm{g} \mathrm{GnRH}$ at the time of introduction of rams to anestrous ewes did not benefit plasma $\mathrm{P}_{4}$ concentrations, lambing rates, or interval from treatment to lambing in those ewes that did lamb, compared to introduction of rams alone. However, GnRH at a dose of $50 \mu \mathrm{g}$ (s.c.) was optimal for evoking release of $\mathrm{LH}$ in lactating ewes and resulted in ovulation in 50 to $70 \%$ of treated ewes (Restall and Radford, 1974). McLeod and colleagues (1982) revealed that injection of 250, 500, or $1000 \mathrm{ng} \mathrm{GnRH} \mathrm{(i.v.)} \mathrm{at} \mathrm{2-hour} \mathrm{intervals} \mathrm{for} 8$ days to anestrous ewes resulted in ovulation in all cases, followed by normal luteal function. 
Increasing the frequency of GnRH secretory episodes from an apparent endogenous level of one episode per 3.6 hours to at least one every 3.0 hours, by exogenous treatment, restored cyclic ovarian activity to seasonally anestrous sheep (McNatty et al., 1982). The questions of optimal timing and dosage of treatment with $\mathrm{GnRH}$ and their effects when combined with introduction of rams continue to be addressed today and are the basis of experiments discussed in this thesis.

\section{Manipulation of Light}

According to Robinson (1990), photoperiodic signals time the breeding seasons of ewes by synchronizing, rather than generating, a rhythm in reproductive neuroendocrine function. Effects of light on reproductive seasonality are mediated through changes in melatonin secretion. It appears that refractoriness to long daylengths times the onset of the breeding season. As reviewed by Gordon (1997), short daylengths can stimulate ovarian activity in sheep from temperate latitudes, but may cause photorefractoriness when used for an extended period of time. Therefore, it is evident that alternation between long and short daylengths is necessary for the photoperiodic control of seasonal reproduction in the ewe. Malpaux and colleagues (1989) concluded that the lengthening photoperiod between the winter and summer solstices is required for the occurrence of the autumn breeding season. Evidence has shown that improved sperm production and quality in rams can be achieved through monthly alternation between long and short days; however, similar treatment does not abolish the seasonality of ovulatory activity in ewes (Pelletier and Almeida, 1987; Gordon, 1997).

As reviewed by Hafez (1952), there are two main types of control of artificial daylength, each of which can advance onset of the breeding season in ewes. The gradual 
system involves a slow decrease or increase in artificial daylength, similar to that occurring under a natural daylength environment. The abrupt system subjects ewes to an abrupt decrease on one day, thereafter maintaining them at that daylength until a response is shown.

The response of ewes to any light manipulation is not immediate and may take months to appear. However, the time of year during which light treatment is applied, as well as the magnitude of the change, is known to have a marked effect on the relative interval to response (Ducker and Bowman, 1970a). In the UK, inducing ewes to breed by an abrupt decrease in photoperiod initiated soon after the longest day in June was much more effective than the same treatment applied when natural day length was increasing and ewes had just entered anestrus (Ducker and Bowman, 1970b). A disadvantage to using light control, however, is that individual ewes show estrus after varying intervals of exposure so that several weeks may pass between onset of estrus in the first and last ewe under treatment (Gordon, 1997).

There are many different regimens of light treatment. Ducker and Bowman (1972) used a system involving the abrupt extension of daylength to 22 hours either in late pregnancy or at parturition, followed by a reduction to that of natural daylength. Newton and Betts (1972) used a system involving an abrupt increase in day length to a constant amount of 18 hours for one month during late pregnancy followed by an abrupt decrease to a constant level of 8 hours, which resulted in inducing fertile estrus within about 3 months after parturition in March-lambing ewes. Supplemental lighting and/or lightproof housing required by some regimens govern the choice of artificial light manipulation schemes for advancing the breeding season in anestrous ewes. 


\section{Melatonin treatment}

During daylight, concentrations of melatonin in plasma are undetectable. With the onset of darkness, melatonin rises rapidly to peak values, which are maintained until near the end of night, depending on duration of darkness. Alteration of photoperiod modifies the amplitude and duration of the melatonin signal and changes it's circadian rhythm. Two major hypotheses have emerged regarding the critical parameters of the melatonin signal. The "phase hypothesis" is that an innate circadian rhythm of sensitivity exists which is entrained by the light:dark cycle and when the melatonin signal coincides with this sensitive period, a photoperiodic response is elicited (Watson-Whitmyre and Stetson, 1983). Watson-Whitmyre and Stetson (1983) tested this hypothesis in pinealectomized male hamsters that were stimulated to breed by increasing photoperiod and were maintained on a constant schedule of 14 hours light and 10 hours dark. Half of the animals were injected with melatonin at the time of the endogenous melatonin peak ( 2 hours prior to lights on) and in the evening ( 0.5 hours prior to lights out) and experienced rapid testicular regression. The other half of the animals were injected with melatonin at the same frequency but at a different time of day and did not experience gonadal regression. Therefore, the "phase hypothesis" rejects that idea that melatonin can illicit a response just by being present, regardless of time of treatment relative to the animals' endogenous circadian rhythm. The "duration hypothesis" is that a photoperiodic response of an animal is dependent on the length of exposure to a continuous melatonin signal, independent of when it occurs (Karsch et al, 1984). 
The pivotal role played by melatonin in seasonal reproduction in ewes is well established. Pinealectomy prevents photoperiod-induced gonadal responses, while exogenous administration of melatonin can be used to mimic the effect of shortening daylength (reviewed by Williams and Helliwell, 1993). Numerous experiments have tested various protocols involving melatonin and have produced varied results. Waller and colleagues (1988) found that in anestrous ewes treated orally with 2 mg melatonin daily, the number of estrous cycles and ram marks were higher than in control ewes and similar to those in ewes given melatonin, progesterone, and pregnant mare serum gonadotropin. Wheaton and colleagues (1990) evaluated the effects of $3 \mathrm{mg}$ oral melatonin given once daily on serum concentrations of LH and prolactin and fertility in spring and summer. The authors found that melatonin decreased secretion of prolactin but had no effect on $\mathrm{LH}$ secretion in response to GnRH. Intervals from introduction of rams to estrus and days to conception were reduced by melatonin, which advanced the onset of the breeding season during summer but did not enhance fertility in spring (Wheaton et al., 1990).

Elucidating optimally effective dosages, routes of administration, and durations of treatment with melatonin has been the subject of many research studies. In a study by Stellflug and colleagues (1988), different concentrations (2 or $10 \mathrm{mg}$ ), routes of administration (fed or implanted), and durations of treatment (20 or 40 days before start of breeding) were studied in ewes during late March and April. The authors found that feeding 2 or $10 \mathrm{mg}$ melatonin or implanting melatonin for 40 days enhanced reproductive performance and effectively overcame the restrictions of seasonality of breeding in mature ewes. Age of the ewe may affect the efficacy of treatment with melatonin. 
Stellflug et al. (1988) found that more mature ewes (> 1.5 years of age) than young ewes lambed after treatment with melatonin. English and colleagues (1986) compared a subcutaneous injection of melatonin, daily oral melatonin administration, and an artificial photoperiod of 8L:16D for ability to advance estrus in anestrous ewes. Melatonin implants in June, but not April or May, advanced onset of estrus in non-lactating adult ewes and there was no difference in the fertility of ewes implanted with or fed melatonin or exposed to artificially shortened photoperiods. Carlson (2000) found that there was an additive effect of melatonin implants and progesterone, which substantially increased pregnancy rates in anestrous ewes compared to non-treated controls. Ronayne et al. (1989) found that the first time at which $\mathrm{P}_{4}$ concentrations were greater $(\mathrm{p}<0.01)$ in ewes implanted with $700 \mathrm{mg}$ melatonin implants than in control ewes occurred 66 days after implantation. Williams and Helliwell (1993) also found that a period of 60 days was required after implantation before beneficial effects of treatment with melatonin on reproductive performance in anestrous ewes was observed. O'Callaghan and colleagues (1991) concluded that $700 \mathrm{mg}$ continuous-release melatonin implants influenced the timing of seasonal reproduction in the ewe by mimicking the effect of short photoperiod. It is difficult or impossible to provide a practical way of placing animals under decreasing daylength during the anestrous period under most production systems. Therefore, the administration of exogenous melatonin becomes a way to "trick" sheep into perceiving decreasing daylength without the management problems associated with artificial lighting regimens. 


\section{Statement of the Problem}

The main economic incentives for inducing ewes to breed more than once per year are to reduce the costs per offspring reared and to increase net return and production per dollar of capital investment. Accelerated lambing could provide a more uniform supply of lamb throughout the year and allow producers to take advantage of higher and more stable prices for their products.

Attempts to breed ewes during anestrus have relied mainly on introduction of rams to induce ewes to cycle. A single injection of $\mathrm{P}_{4}$ at the time of introduction of rams can improve conception and pregnancy rates of ewes bred out-of-season by ensuring normal luteal lifespan following the first ram-induced ovulation so that conception can occur after treatment with $\mathrm{PGF}_{2} \alpha$. Although numerous studies have proven the efficacy of $\mathrm{P}_{4}$ to improve the effectiveness of introduction of rams, it is not readily available to sheep producers. Therefore, investigation of other approaches of improving the response of anestrous ewes to introduction of rams is warranted.

Gonadotropin-releasing hormone, which may be available to sheep producers through a veterinary-client relationship, is a possible substitute for exogenous $\mathrm{P}_{4}$ in outof-season breeding approaches by inducing an endogenous supply of $\mathrm{P}_{4}$ and by causing more ewes to ovulate in response to rams. Although numerous studies have been conducted on the use of GnRH in cattle, few studies have evaluated its effects in anestrous ewes. Experiments 1 and 2 were conducted to determine if treatment with $\mathrm{GnRH}$ increased the percentage of anestrous ewes that ovulated and lambed following introduction of rams. 
Both the depth of anestrus and the lactational status of the ewe affect the ovulatory response to introduction of rams. For example, the response of ewes to introduction of rams is greater during the transition into the breeding season than during the middle of anestrus. Experiment 3 was conducted to determine if treatment with melatonin, which mimics a short-day photoperiod, affected the percentage of anestrous ewes that ovulated in response to introduction of rams and whether this effect was modified by lactational status. 


\section{Introduction}

The peak in breeding activity of the ewe occurs from September to November in the Northern Hemisphere and is reflected in a subsequent peak in lambing activity from February to April. Breeding and lambing patterns are reflected in seasonal availability of lamb and fluctuations in price. Incentives to breed ewes more than once per year include reduced costs per offspring reared, increased net return, increased production per dollar of capital investment, a more uniform supply of lamb throughout the year, and more consistent lamb prices. Because sheep are seasonally polyestrous, an attempt to mate at a frequency greater than once a year will require one breeding season during or near anestrus. Without intervening treatments during anestrus, little ovarian and estrous activity occurs, and pregnancy and conception rates are low, especially if out-of-season breeding occurs during the early postpartum period.

Attempts to breed ewes during anestrus have relied mainly on the abrupt introduction of rams, which induces an LH surge and ovulation and is referred to as the "ram-effect" (Underwood et al., 1944; Schinckel, 1954). However, the response to introduction of rams is variable and is affected by both ram- and ewe-associated factors, including lactational status, depth of anestrus, nutritional status, breed and sexual activity of the ram and ewe (reviewed by Knights et al., 2004). Additionally, some ewes might revert to an anestrous state prior to a subsequent ovulation or before displaying estrus, preventing them from being mated and conceiving. Therefore, the ram effect by itself is not adequate for breeding ewes out-of-season.

The endocrine and behavioral events following the introduction of rams closely mimic the events of the follicular phase except that estrus is not evident (Knights, 2001). 
Additionally, in 50\% or more of the ram-induced ovulations, the resultant CL can regress prematurely, precluding the establishment of a normal luteal phase (Oldham and Martin, 1978). If the resultant CL from the first ram-induced ovulation is normal, it can provide an endogenous source of $\mathrm{P}_{4}$ that would allow estrus and possible conception at a subsequent ovulation. Exogenous $\mathrm{P}_{4}$ combined with the ram effect can be used to improve conception and pregnancy rates of ewes bred out-of season. Both estrus and conception can occur at the first ram-induced ovulation when $\mathrm{P}_{4}$ is provided 4 to 5 days prior to introduction of rams (Oldham et al., 1985; Martin et al., 1986). Alternatively, a single injection of $\mathrm{P}_{4}$ at the time of introduction of rams completely prevents the occurrence of CL with short lifespans (Pearce et al., 1985) and provides the opportunity for $\mathrm{PGF}_{2} \alpha$-induced estrous synchronization during the luteal phase. Therefore, this treatment can be used to prevent the premature regression of $\mathrm{CL}$ and to allow more ewes to display estrus at subsequent ovulations. Currently no form of $\mathrm{P}_{4}$ is available for use in the sheep industry in the United States. Additionally, $\mathrm{P}_{4}$ treatment alone does not address the low ovulatory response observed in some cases after introduction of rams. Additional approaches are therefore warranted.

Gonadotropin releasing hormone is currently approved for use in sheep in the United States and has been shown to induce ovulation in anestrous ewes (Crighton et al., 1973; Haresign et al., 1975). Therefore GnRH might be used to enhance the percentage of ewes ovulating following the introduction of rams, or to induce ovulation and luteinization to provide anestrous ewes with brief exposure to $\mathrm{P}_{4}$ prior to the ram-induced ovulation. 
Both the depth of anestrus and the lactational status of the ewe affect the ovulatory response to introduction of rams. For example, the response of ewes to introduction of rams is greater during the transition into the breeding season than during the middle of anestrus. In the following studies, the effects of GnRH and melatonin on the ovulatory and reproductive performance of ewes exposed to rams during the anestrous period were investigated. 


\section{Materials and Methods}

\section{General}

The studies were conducted on two private farms in Randolph County and Reymann Memorial Farm of West Virginia University in Hardy County, West Virginia. Ewes were managed on native grass pastures and brought into barns for treatment or maintained in a barn and holding lot and fed hay and grain daily during the treatment period (Experiment 2B). In general, animals were managed in a manner typical of eastern commercial farm flocks.

In all studies, the ewe to ram ratio was not greater than 15 ewes per ram. Treatment for synchronization of induced estrus consisted of $20 \mathrm{mg} \mathrm{PGF}_{2} \alpha$ (4 mL Lutalyse, Pfizer Animal Health, i.m.).

\section{Blood collection and storage}

All blood samples $(5 \mathrm{~mL})$ were obtained by jugular venipuncture and stored in glass tubes at 4 degrees $\mathrm{C}$ and allowed to clot. Serum samples were collected within 12 hours and frozen at -20 degrees $\mathrm{C}$. 
Experiment 1: Effect of treatment with GnRH 2 days after introduction of rams on the reproductive performance of ewes bred during anestrus

This study was conducted on two farms in June 2003, utilizing a total of 112 nonlactating ewes of primarily Suffolk and Dorset breeding. The timelines for Experiment 1 are shown in Figure 1. Ewes were assigned randomly to one of two treatment groups: group 1) introduction of rams alone ( $\mathrm{n}=65)$, or group 2) $100 \mu \mathrm{g} \mathrm{GnRH}(4 \mathrm{ml}$ Cystorelin, Merial Ltd.; i.m.) 2 days after introduction of rams $(n=47)$. Raddled, intact rams were introduced on day 0 at which time all ewes received $25 \mathrm{mg} \mathrm{P}$ (i.m.) in corn oil. All ewes were treated with $\mathrm{PGF}_{2} \alpha$ on day 14. Ovaries were examined for the presence of corpora lutea by transrectal ultrasonography on day 14 on one farm. Pregnancy was determined by ultrasonography 32 days after treatment with $\mathrm{PGF}_{2} \alpha$ and all lambing data were recorded. 
Figure 1. Timelines for treatment groups in Experiment 1.

\section{Group 1:}

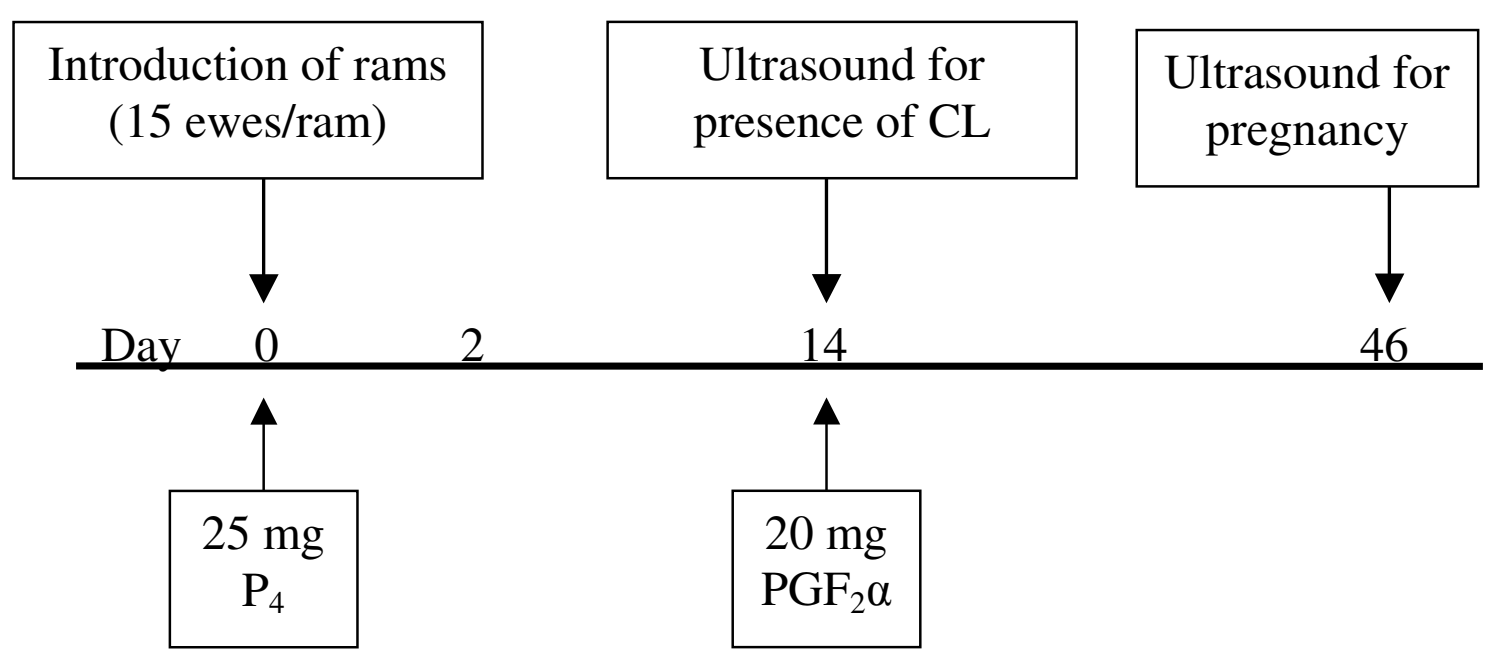

Group 2:

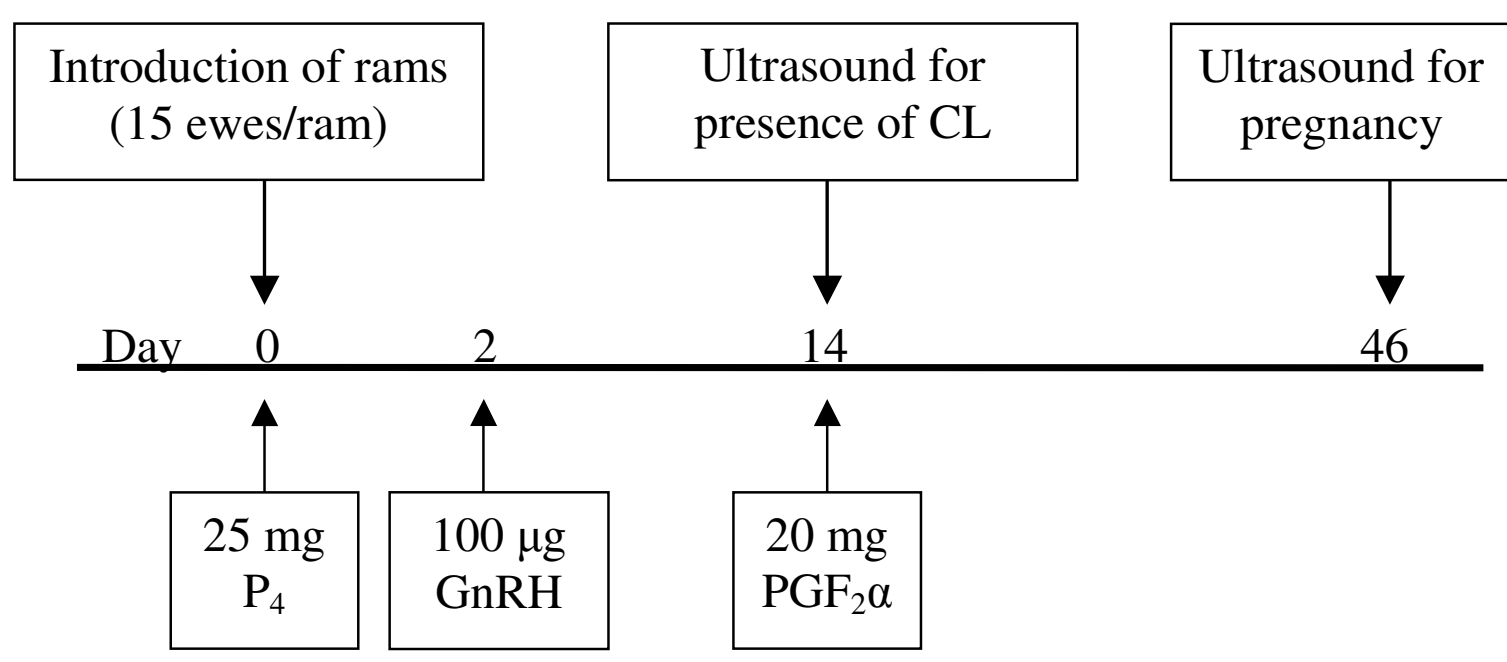


Experiment 2: Effect of day of treatment with GnRH relative to introduction of rams on the induction of ovulation and formation of $\mathrm{CL}$ in ewes introduced to rams during anestrus

\section{A. Comparison of treatment with GnRH 2 and/or 7 days after introduction of rams}

This study was conducted in June 2003, utilizing a total of 89 non-lactating ewes of primarily Suffolk, Dorset, and Katahdin breeding. The timelines for Experiment 2A are shown in Figure 2. Ewes were assigned randomly to one of the following treatment groups: group 1) $100 \mu \mathrm{g}$ GnRH (2 ml Fertagyl, Intervet, Inc.; i.m.) 2 days after introduction of rams ( $\mathrm{n}=29)$, group 2) $100 \mu \mathrm{g}$ GnRH 7 days after introduction of rams ( $\mathrm{n}$ = 28), or group 3) $100 \mu \mathrm{g} \mathrm{GnRH}$ both 2 and 7 days after introduction of rams $(\mathrm{n}=32)$. Raddled, intact rams of proven fertility, were introduced to ewes on day 0. All ewes were treated with $\mathrm{PGF}_{2} \alpha$ on day 14. On days 7 and 14, ovaries of a subset of ewes in each group were examined by transrectal ultrasonography and number of corpora lutea, number of follicles larger than $4 \mathrm{~mm}$, and size of the 3 largest follicles were recorded for each ovary. Ewes were observed for raddle marks on day 18. Pregnancy was determined by ultrasonography 38 and 53 days after treatment with $\mathrm{PGF}_{2} \alpha$ and all lambing data were recorded. 
Figure 2. Timelines for treatment groups in Experiment 2A.

\section{Group 1:}

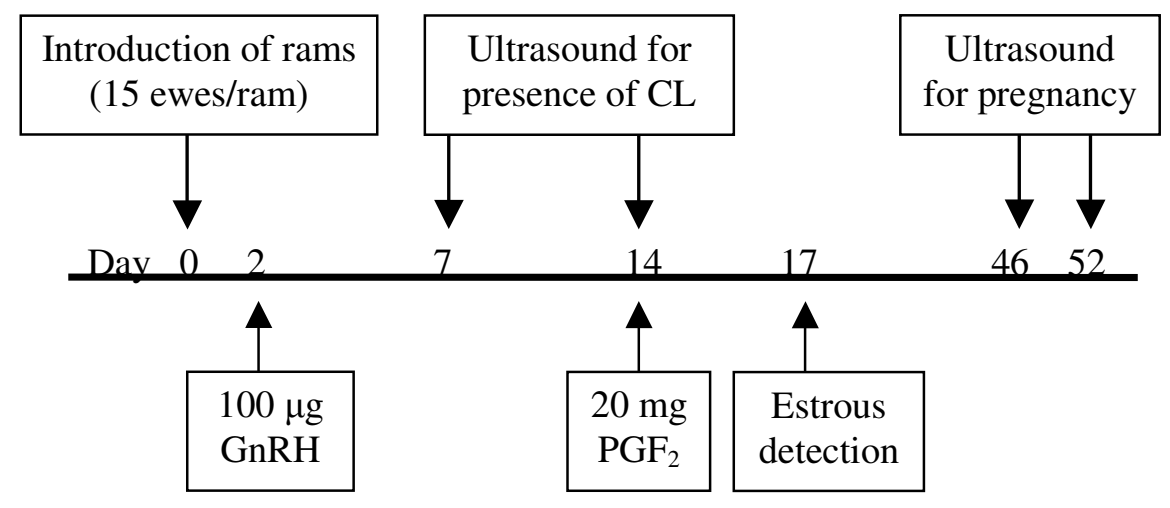

\section{Group 2:}

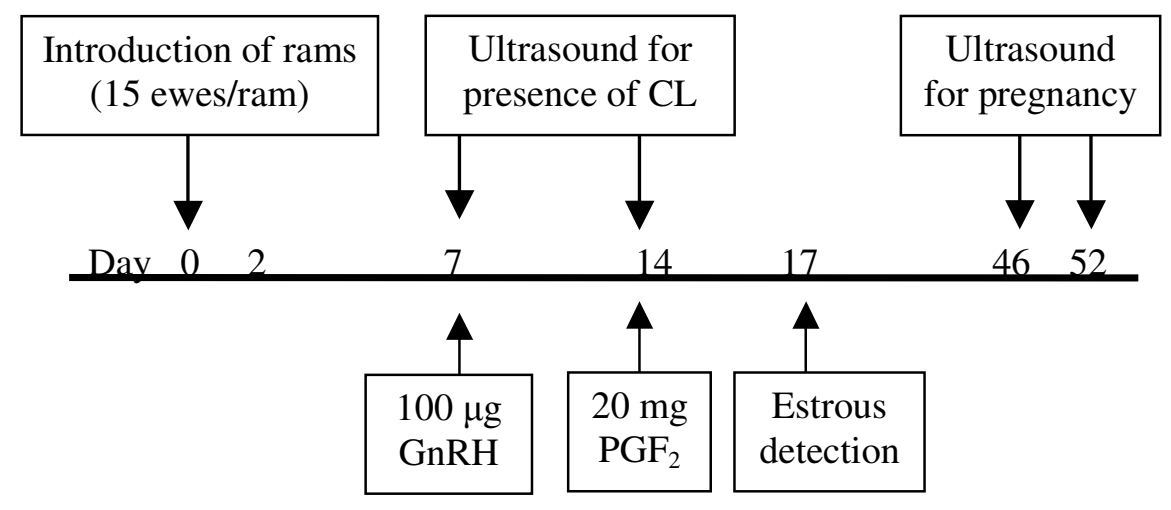

\section{Group 3:}

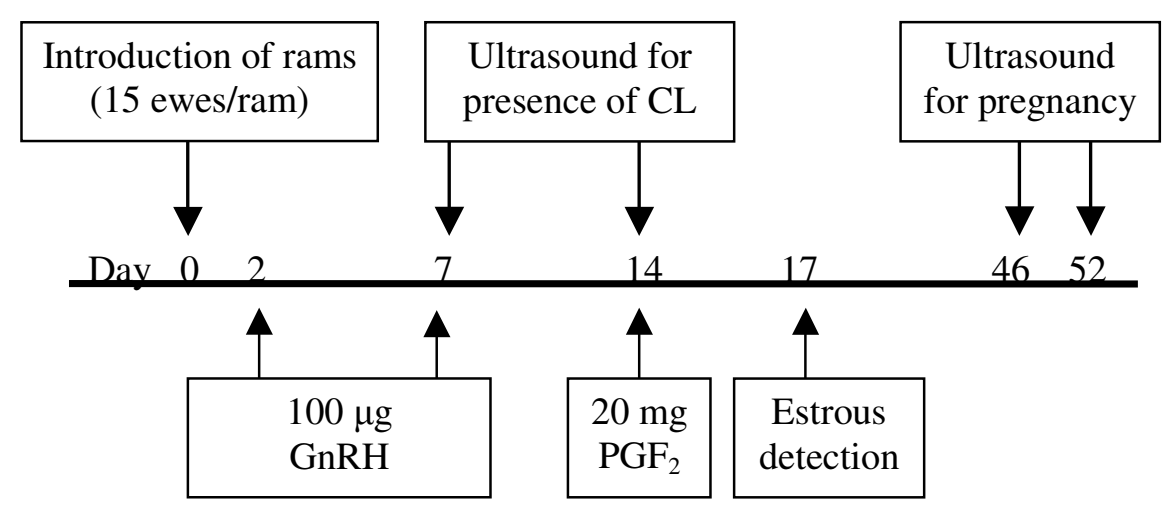




\section{B. Comparison of treatment with GnRH 4 days before and/or 1 day after introduction of rams or progesterone at introduction of rams}

This study was conducted in June 2004, utilizing a total of 85 non-lactating ewes of primarily Suffolk, Dorset, and Katahdin breeding. Plasma samples were collected prior to the start of the experiment and were assayed for concentration of $\mathrm{P}_{4}$. Ewes with concentrations of $\mathrm{P}_{4}$ greater than $1 \mathrm{ng} / \mathrm{mL}$ were considered to be cycling and were not included in the experiment. The timelines for experiment $2 \mathrm{~B}$ are shown in Figure 3. Anestrous ewes were assigned randomly to one of the following treatment groups: group 1) introduction of rams alone ( $\mathrm{n}=21)$, group 2) $100 \mu \mathrm{g}$ GnRH (2 ml Fertagyl, Intervet, Inc.; i.m.) 4 days before introduction of rams $(\mathrm{n}=22)$, group 3) $100 \mu \mathrm{g} \mathrm{GnRH} 4$ days before and 1 day after introduction of rams $(\mathrm{n}=21)$, or group 4) a single injection of $25 \mathrm{mg} \mathrm{P}$ (i.m.) in corn oil on the day of introduction of rams $(n=21)$. Raddled, intact rams were introduced to ewes on day 0 . All ewes were treated with $\mathrm{PGF}_{2} \alpha$ on day 12.

Blood samples were collected from day -4 to day 10 on a subset of ewes from each group. On days 11 and 12, blood samples were collected from all ewes with half of the ewes being collected each day. Blood samples on days $-4,0,1$, and 9 were collected before 12

pm. Blood samples on days $-3,-2,-1,2,3,4,5,6,7,8$, and 10 were collected in both morning and evening and pooled for daily $\mathrm{P}_{4}$ determination. Blood samples on days 11 and 12 were collected from 6 am to 4 pm.

Occurrence of ovulation was determined by $\mathrm{P}_{4}$ concentrations $>1 \mathrm{ng} / \mathrm{mL}$ on days 0,7 , 11 , and 12 and by ultrasonographic analysis of ovaries for the presence of CL on days 11 and 12. The number of ewes marked by rams was recorded 6 days after treatment with $\mathrm{PGF}_{2} \alpha$. Pregnancy was determined by ultrasonography 22 and 92 days after $\mathrm{PGF}_{2} \alpha$ and all lambing data were recorded. 
Figure 3. Timelines for treatment groups in Experiment 2B.

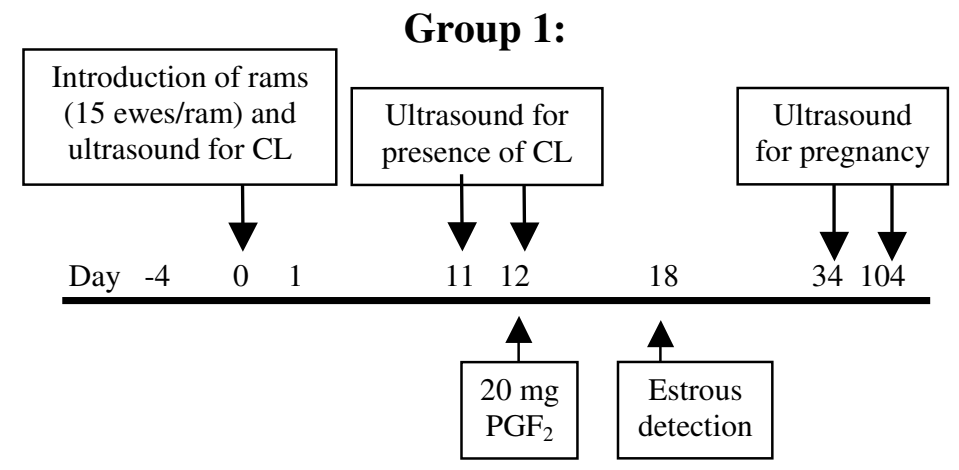

\section{Group 2:}

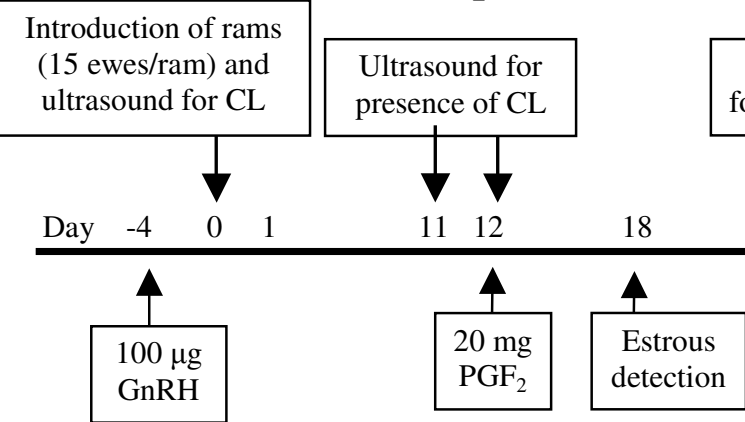

\section{Group 3:}

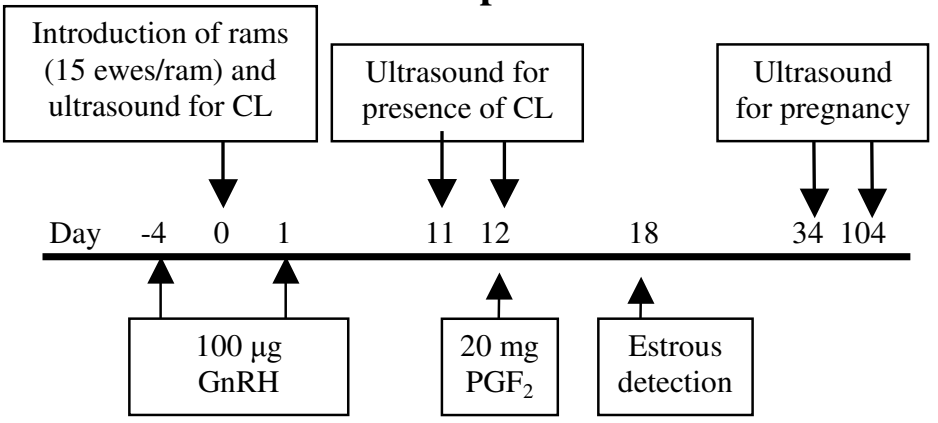

\section{Group 4:}

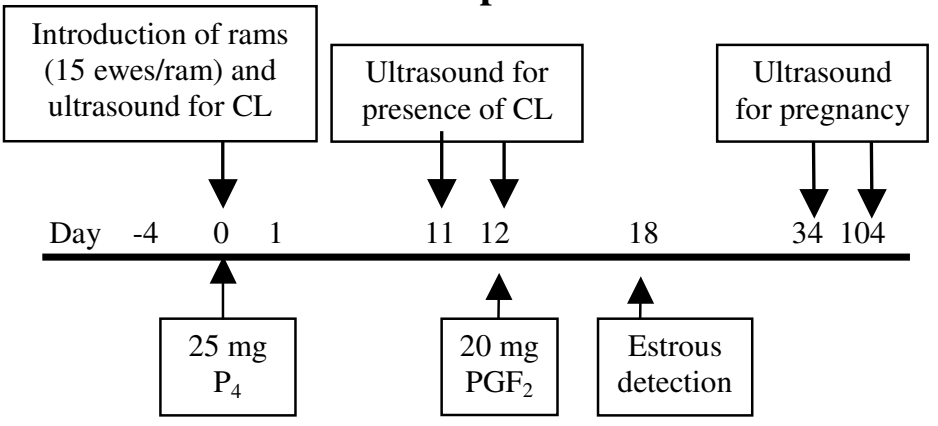


Experiment 3: Effect of lactational status and pretreatment with melatonin on the ovulatory response and reproductive performance of ewes exposed to rams during anestrus

This study was conducted in May 2004, utilizing a total of 144 lactating ewes and 117 non-lactating ewes of primarily Suffolk and Dorset breeding. The timelines for experiment 3 are shown in Figure 4. Ewes were assigned to one of the following treatment groups: group 1) non-lactating control ewes $(\mathrm{n}=50)$, group 2) non-lactating ewes treated with melatonin $(n=52)$, group 3$)$ lactating control ewes $(n=50)$, or group 4) lactating ewes treated with melatonin $(n=49)$. Thirty-five days after implantation of melatonin, 45 lactating ewes not treated with melatonin and 15 non-lactating ewes not treated with melatonin were added to the experiment. Ewes receiving melatonin were given a subcutaneous implant containing $18 \mathrm{mg}$ melatonin (Regulin, Ceva Sante Animale) inserted at the rear base of the ear in late May. The implants have been shown to maintain plasma concentrations of melatonin above $232 \mathrm{ng} / \mathrm{mL}$ for 10 days (Stellflug et al., 1988). The day of melatonin implantation was considered day 0 . All ewes were treated with $25 \mathrm{mg} \mathrm{P}_{4}$ (i.m.) in corn oil on day 35 at which time raddled, intact rams were put with the ewes. All ewes were treated with $\mathrm{PGF}_{2} \alpha$ on day 49. Lambing data were recorded. Blood samples were collected on days 0,35 , and 49 and occurrence of ovulation was determined by $\mathrm{P}_{4}$ concentrations $>1 \mathrm{ng} / \mathrm{mL}$ on these days. Serum was assayed for $\mathrm{P}_{4}$ and melatonin concentrations at each of the three sampling time points. 
Figure 4. Timelines for treatment groups in Experiment 3.

Groups 1 (non-lactating) and 3 (lactating):

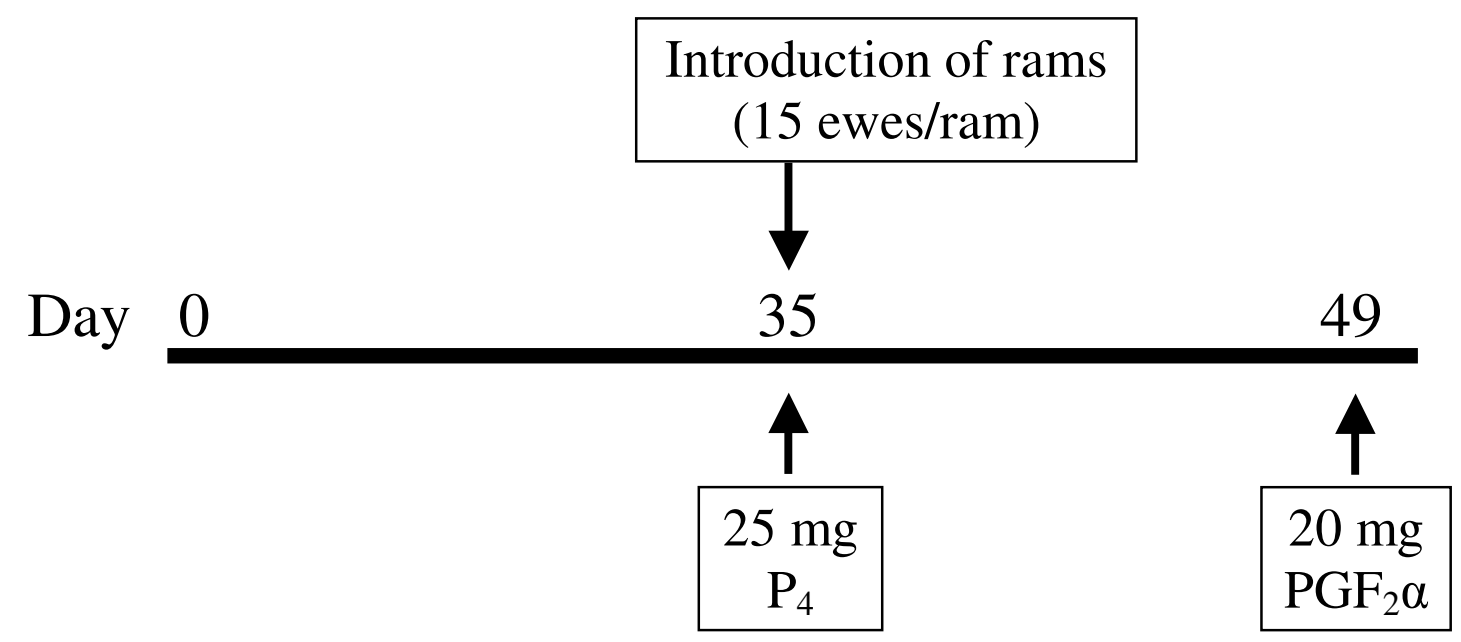

Groups 2 (non-lactating) and 4 (lactating):

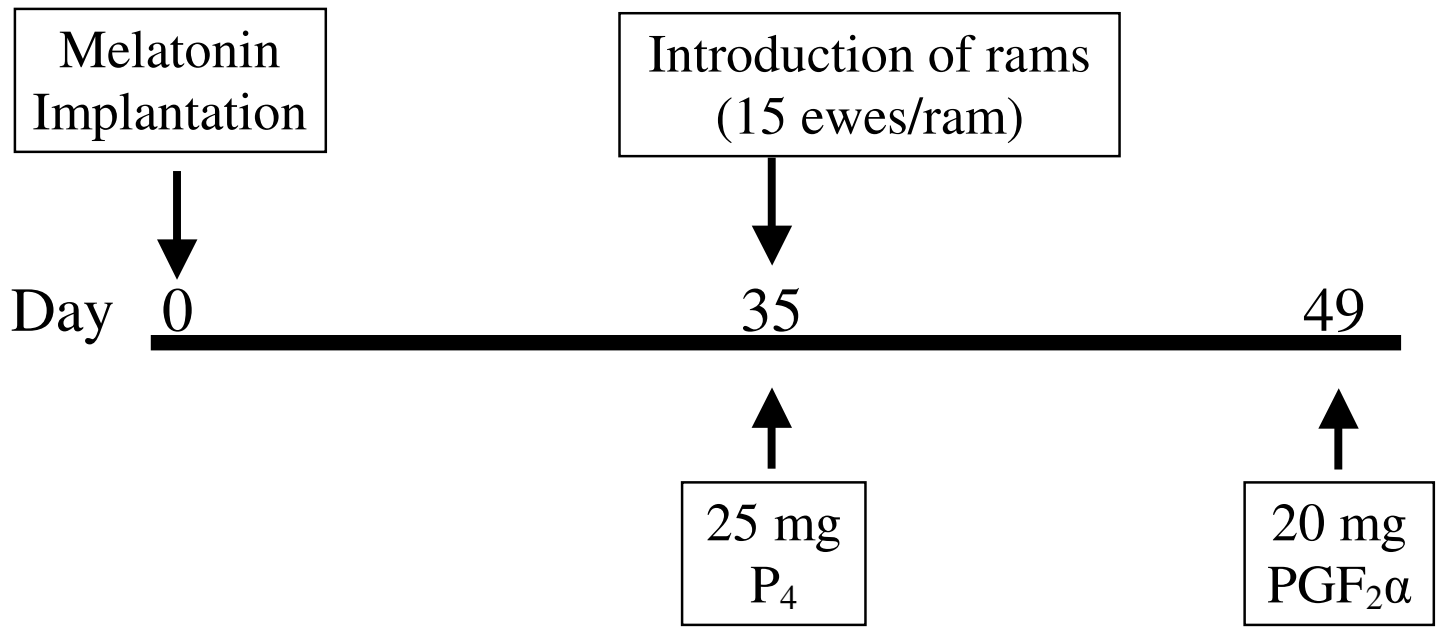




\section{Assays for Progesterone and Melatonin}

Serum was assayed for $\mathrm{P}_{4}$ concentration with the Coat-A-Count Progesterone Kit (Diagnostic Products Corporation), as described and validated by Kubasik et al. (1984). The assay was sensitive to $0.02 \mathrm{ng} / \mathrm{mL}$ and the coefficient of variation was $13 \%$.

Serum was assayed for melatonin concentration with the Melatonin Research RIA (Labor Diagnostika Nord GmbH \& Co.), as described and validated by Manz et al. (1989). The assay was sensitive to $1.3 \mathrm{pg} / \mathrm{mL}$ and the coefficient of variation was $10 \%$.

\section{Statistical Analysis}

Experiment 1

Proportions of ewes that responded to the treatments were analyzed with logistic regression using the LOGISTIC procedures of SAS (SAS Inst. Inc, Cary, N.C.). Response variables included percentages of ewes with a CL present 14 days after ram introduction, percentages of ewes pregnant 32 days after treatment with $\mathrm{PGF}_{2} \alpha$, and percentages of ewes lambing to all services. Results were calculated as the percentage of ewes displaying the variable of all ewes treated. Effects of treatment and farm were tested as well as the interaction of these two variables.

\section{$\underline{\text { Experiment } 2}$}

A Proportions of ewes in the original treatment groups that responded to the treatments were analyzed with logistic regression using the LOGISTIC procedures of SAS. The effects of treatment and face color were tested, as well as their interaction. Orthogonal contrasts tested were GnRH on both days vs. GnRH on day 2 or GnRH on 
day 7 and GnRH on day 2 vs. GnRH day on 7. Response variables included percentages of ewes with a CL present 7 and 14 days after ram introduction, the total numbers of CL present for each group 7 and 14 days after ram introduction, the percentages of ewes with a follicle $>4 \mathrm{~mm}$ present 7 and 14 days after ram introduction, the average size $(\mathrm{mm})$ of the 3 largest follicles on the ovary 7 and 14 days after ram introduction, percentages of ewes marked by rams 4 days after treatment with $\mathrm{PGF}_{2} \alpha$, percentages of ewes pregnant at 38 and 53 days after treatment with $\mathrm{PGF}_{2} \alpha$, and percentages of ewes lambing to the first and second service periods. Ewes lambing to first service was expressed as a percentage of all ewes treated, while ewes lambing to second service was expressed as a percentage of those ewes that didn't lamb to first service.

Chi-squared analysis and analysis of variance using the FREQ and GML procedures of SAS were conducted once data had been reclassified into groups according to presence of CL at days 7 and 14 . Response variables were the same as those analyzed for the original treatment groups.

B Categorical data were analyzed with Fisher's exact probability tests, chisquared analysis, and logistic regression using the FREQ and LOGISTIC procedures of SAS. Analysis of variance using the GLM procedure of SAS was utilized to examine continuous data. Orthogonal contrasts tested included control ewes vs. ewes receiving GnRH or $\mathrm{P}_{4}$, ewes receiving GnRH vs. ewes receiving $\mathrm{P}_{4}$, and ewes receiving GnRH 4 days before ram introduction vs. ewes receiving GnRH 4 days before and 1 day after ram introduction. Categorical response variables included percentages of ewes with a $\mathrm{P}_{4}$ concentration $>1 \mathrm{ng} / \mathrm{mL}$, which was analyzed for day 0 , day 7 , and days 11 and 12 combined, percentages of ewes marked by rams after treatment with $\mathrm{PGF}_{2} \alpha$, percentages 
of ewes with a CL 11 days after treatment with $\mathrm{PGF}_{2} \alpha$, percentages of ewes pregnant 22 and 95 days after induced estrus, and percentages of ewes lambing to the first, second, third, and all service periods. Percentages of ewes lambing to first and second service periods were examined as in Experiment 2A, and to third service as a percentage of ewes that didn't lamb to the first two service periods. Ewes lambing to all services and all other data were examined as percentages of all ewes treated or sampled. The continuous response variable, number of days from treatment with $\mathrm{PGF}_{2} \alpha$ to lambing, was calculated including only those ewes that lambed. The number of CL present on day 11 also was considered a continuous variable and was analyzed by ANOVA.

\section{Experiment 3}

Concentrations of melatonin on days 0,35 , and 49 relative to melatonin implantation were examined by analysis of variance using the MIXED procedures of SAS. Analysis of variance was also conducted on the percentages of ewes with $\mathrm{P}_{4}$ concentrations $>1 \mathrm{ng} / \mathrm{mL}$ on days 0,35 , and 49 using the GLM procedures of SAS. Logistic regression was conducted on the percentage of ewes lambing using the LOGISTIC procedures of SAS. Percentages were based upon all ewes treated or sampled. 


\section{Results}

\section{Experiment 1}

Treatment with GnRH 2 days after introduction of rams did not significantly increase percentages of ewes with a CL on day 14 after introduction of rams $(85.7 \%)$, pregnant 32 days after $\mathrm{PGF}_{2} \alpha$ treatment (34.1\%), or lambing (37.2\%). Effects of treatment with GnRH 2 days after introduction of rams on reproductive performance variables are presented in Table 1.

There was a significant effect of farm on pregnancy rates and percentages of ewes lambing. Higher percentages of ewes on Farm 2 were pregnant 32 days after treatment with $\mathrm{PGF}_{2} \alpha$ and lambed (both 62.2\%) than ewes on Farm 1 (12.9 and 19.1\%; p < 0.0001; Table 2). 
Table 1. Effect of treatment with GnRH on formation of CL, occurrence of estrus, pregnancy rates, and ewes lambing.

\begin{tabular}{lcc}
\hline \multicolumn{1}{c}{ Variable } & \multicolumn{2}{c}{ Treatment } \\
\hline $\mathbf{N}$ & Control & $\mathbf{1 0 0} \boldsymbol{\mu g}$ GnRH day 2 \\
\hline $\begin{array}{lc}\text { Percentage of ewes with detectable } \\
\text { CL on day 14 }\end{array}$ & 66 & 47 \\
& 76.9 & 94.4 \\
$\begin{array}{l}\text { Percentage of ewes pregnant on } \\
\text { day 32 after induced estrus a }\end{array}$ & $(20 / 26)$ & $(17 / 18)$ \\
& 31.7 & 26.4 \\
& $(20 / 63)$ & $(16 / 44)$ \\
$\begin{array}{l}\text { Percentage of ewes that lambed } \\
\text { overall }\end{array}$ & 31.8 & 42.6 \\
\hline
\end{tabular}

${ }^{\mathrm{a}}$ Some ewes were unavailable for pregnancy diagnosis on day 32. 
Table 2. Percentages of ewes pregnant and lambing by farm.

\begin{tabular}{|c|c|c|}
\hline \multirow[t]{2}{*}{ Variable } & \multicolumn{2}{|c|}{ Farm } \\
\hline & 1 & 2 \\
\hline $\mathbf{N}$ & 68 & 45 \\
\hline $\begin{array}{l}\text { Percentage of ewes pregnant on day } 32 \\
\text { after induced estrus a b }\end{array}$ & $\begin{array}{c}12.9 \\
(8 / 62)\end{array}$ & $\begin{array}{c}62.2 \\
(28 / 45)\end{array}$ \\
\hline Percentage of ewes that lambed overall ${ }^{\text {a }}$ & $\begin{array}{c}19.1 \\
(13 / 68)\end{array}$ & $\begin{array}{c}62.2 \\
(28 / 45)\end{array}$ \\
\hline
\end{tabular}

a 1 vs 2: $\mathrm{p}<0.0001$

${ }^{\mathrm{b}}$ Six ewes on Farm 1 were unavailable for pregnancy diagnosis on day 32. 


\section{Experiment 2}

A. The results for experiment $2 \mathrm{~A}$ are presented in Table 3. Treatment with GnRH on days 2,7 , or on both days did not significantly affect the percentage of ewes with a detectable CL (estimated percentage of ewes ovulating), the number of CL present on day 11, or other measures of reproductive performance. The mean estrous response, mean pregnancy rates on days 35 and 50 after treatment with $\mathrm{PGF}_{2} \alpha$, and mean percentages of ewes lambing to the first and second services were 55, 28, 34, 27, and 43\%, respectively (Table 3).

To examine the effect of presence of a CL on days $7 \mathrm{and} /$ or 14 on reproductive traits, ewes were reclassified as having no CL on either day $(n=14)$, a CL on only day $7(n=10)$, a CL on only day $14(n=16)$, or a CL on both days $(n=17)$. Estrous response was greater in ewes in which a CL was detected on day 7 (70\%), day $14(81 \%)$, or both days (81\%) than in those ewes in which a CL was not detected (14\%; $\mathrm{p}<0.01$; Figure 5). Percentages of ewes pregnant 38 days after treatment with $\mathrm{PGF}_{2} \alpha$ tended to be higher $(\mathrm{p}=0.06)$ in ewes in which a CL was detected on both days (53\%) than in ewes in which a CL was detected on only day $7(30 \%)$ or not detected on either day (7\%; Figure 6). Ewes in which a CL was detected on only day $14(38 \%)$ did not differ from those in which a CL was detected on day 7 or on both days. Pregnancy rates on day 53 after treatment with $\mathrm{PGF}_{2} \alpha$ were greater in ewes in which a CL was detected on only day $14(86.7 \%)$ or both days $(80 \%)$ than in ewes in which a CL was not detected on either day (30.8\%; shown in Figure 7). The percentage of ewes lambing to the first service was greater $(p=0.01)$ in ewes in which a CL was detected on both days (47\%) than in those in which a CL was not detected on either day (7\%). More total ewes lambed in groups with CL than in groups without CL (Figure 8). 
Table 3. Effect of time of treatment with GnRH on formation of CL, follicular development, occurrence of estrus, and fertility in Experiment $2 \mathrm{~A}$.

\begin{tabular}{|c|c|c|c|}
\hline \multirow[t]{2}{*}{ Variable } & \multicolumn{3}{|c|}{ Treatment } \\
\hline & $\begin{array}{c}100 \mu \mathrm{g} \\
\text { GnRH day } \\
2 \\
\end{array}$ & $\begin{array}{c}100 \mu \mathrm{g} \\
\text { GnRH day } 7\end{array}$ & $\begin{array}{l}100 \mu \mathrm{g} \text { GnRH } \\
\text { both days }\end{array}$ \\
\hline Total $\mathbf{N}$ & 29 & 28 & 32 \\
\hline Percentage of ewes with a detectable CL on day 7 & $\begin{array}{c}40.0 \\
(8 / 20)\end{array}$ & $\begin{array}{c}44.4 \\
(8 / 18)\end{array}$ & $\begin{array}{c}57.9 \\
(11 / 19)\end{array}$ \\
\hline Percentage of ewes with a detectable CL on day 14 & $\begin{array}{c}60.0 \\
(12 / 20)\end{array}$ & $\begin{array}{c}66.7 \\
(12 / 18)\end{array}$ & $\begin{array}{c}57.9 \\
(11 / 19)\end{array}$ \\
\hline $\begin{array}{l}\text { Percentage of ewes with a detectable CL on both } \\
\text { days }\end{array}$ & $\begin{array}{c}20.0 \\
(4 / 20)\end{array}$ & $\begin{array}{c}33.3 \\
(6 / 18)\end{array}$ & $\begin{array}{c}36.8 \\
(7 / 19)\end{array}$ \\
\hline Numbers of follicles day $7^{\text {a }}$ & $\begin{array}{c}2.4 \\
(47 / 20)\end{array}$ & $\begin{array}{c}1.9 \\
(34 / 18)\end{array}$ & $\begin{array}{c}2.6 \\
(50 / 19)\end{array}$ \\
\hline Diameter of F1 day 7 after RI (mm) & 5.5 & 5.6 & 6.5 \\
\hline Diameter of F2 day 7 after RI (mm) & 5.0 & 4.6 & 4.7 \\
\hline Diameter of F3 day 7 after RI (mm) & 4.7 & 4.3 & 4.1 \\
\hline Numbers of follicles day $14^{\text {a }}$ & $\begin{array}{c}3.0 \\
(59 / 20)\end{array}$ & $\begin{array}{c}2.6 \\
(47 / 18)\end{array}$ & $\begin{array}{c}2.5 \\
(47 / 19)\end{array}$ \\
\hline Diameter of F1 day 14 after RI (mm) & 5.7 & 5.7 & 5.9 \\
\hline Diameter of F2 day 14 after RI (mm) & 5.1 & 5.3 & 4.8 \\
\hline Diameter of F3 day 14 after RI (mm) & 4.7 & 4.7 & 4.4 \\
\hline $\begin{array}{l}\text { Percentage of ewes marked by rams after } \\
\text { treatment with } \mathrm{PGF}_{2} \alpha\end{array}$ & $\begin{array}{c}58.6 \\
(17 / 29)\end{array}$ & $\begin{array}{c}57.1 \\
(16 / 28)\end{array}$ & $\begin{array}{c}50.0 \\
(16 / 32)\end{array}$ \\
\hline $\begin{array}{l}\text { Percentage of ewes pregnant } 38 \text { days after induced } \\
\text { estrus }\end{array}$ & $\begin{array}{c}27.6 \\
(8 / 29)\end{array}$ & $\begin{array}{c}32.1 \\
(9 / 28)\end{array}$ & $\begin{array}{c}25.0 \\
(8 / 32)\end{array}$ \\
\hline $\begin{array}{l}\text { Percentage of ewes pregnant } 53 \text { days after induced } \\
\text { estrus }\end{array}$ & $\begin{array}{c}34.5 \\
(10 / 29)\end{array}$ & $\begin{array}{c}28.6 \\
(8 / 28)\end{array}$ & $\begin{array}{c}40.6 \\
(13 / 32)\end{array}$ \\
\hline Percentage of ewes that lambed to service 1 & $\begin{array}{c}20.7 \\
(6 / 29)\end{array}$ & $\begin{array}{c}28.6 \\
(8 / 28)\end{array}$ & $\begin{array}{c}31.3 \\
(10 / 32)\end{array}$ \\
\hline Percentage of ewes that lambed to service 2 & $\begin{array}{c}47.8 \\
(11 / 23)\end{array}$ & $\begin{array}{c}40.0 \\
(8 / 20)\end{array}$ & $\begin{array}{c}40.9 \\
(9 / 22)\end{array}$ \\
\hline Percentage of ewes that lambed overall & $\begin{array}{c}58.6 \\
(17 / 29)\end{array}$ & $\begin{array}{c}57.1 \\
(16 / 28)\end{array}$ & $\begin{array}{c}59.4 \\
(19 / 32)\end{array}$ \\
\hline
\end{tabular}

\footnotetext{
${ }^{\mathrm{a}}$ Numbers of follicles $>5 \mathrm{~mm}$ on days 7 and 14 after introduction of rams.
} 
Figure 5. Percentage of ewes marked by rams among ewes in which a CL was detected on day 7 or 14 only, detected on both days, or not detected on either day $(\mathrm{a}, \mathrm{b}: \mathrm{p}<0.05)$.

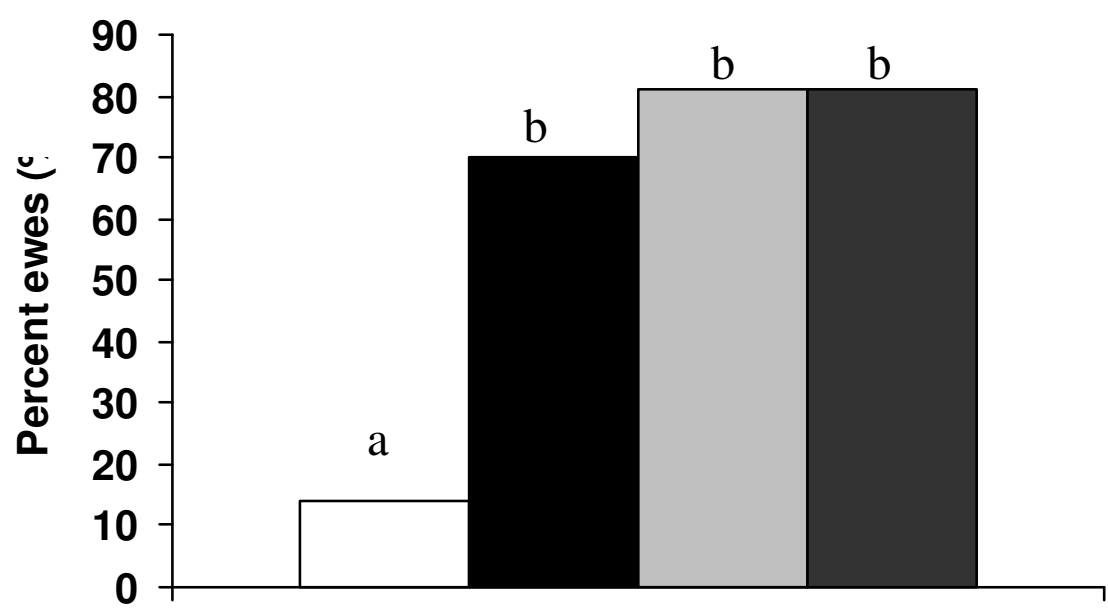

$\square$ No CL $\square$ CL day 7 only $\square$ CL day 14 only $\square$ CL both 
Figure 6. Percentage of ewes pregnant 38 days after induced estrus in ewes in which a CL was detected on day 7 or 14 only, detected on both days, or not detected on either day (a,b: $p<0.05$; CL day 7 vs. CL both days: $p=0.06$ ).

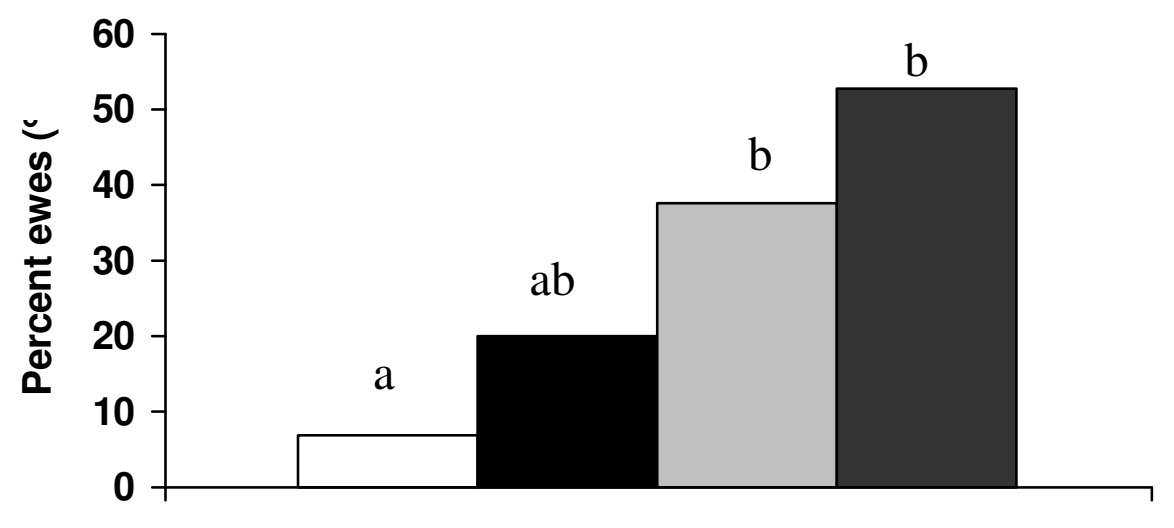

$\square$ No CL $\square$ CL day 7 only $\square$ CL day 14 only $\square$ CL both 
Figure 7. Percentage of ewes pregnant 53 days after induced estrus in ewes in which a CL was detected on day 7 or 14 only, detected on both days, or not detected on either day (a,b: $\mathrm{p}<0.005$; CL day 7 vs. CL day 14 or CL both: $\mathrm{p}=0.09$ ).

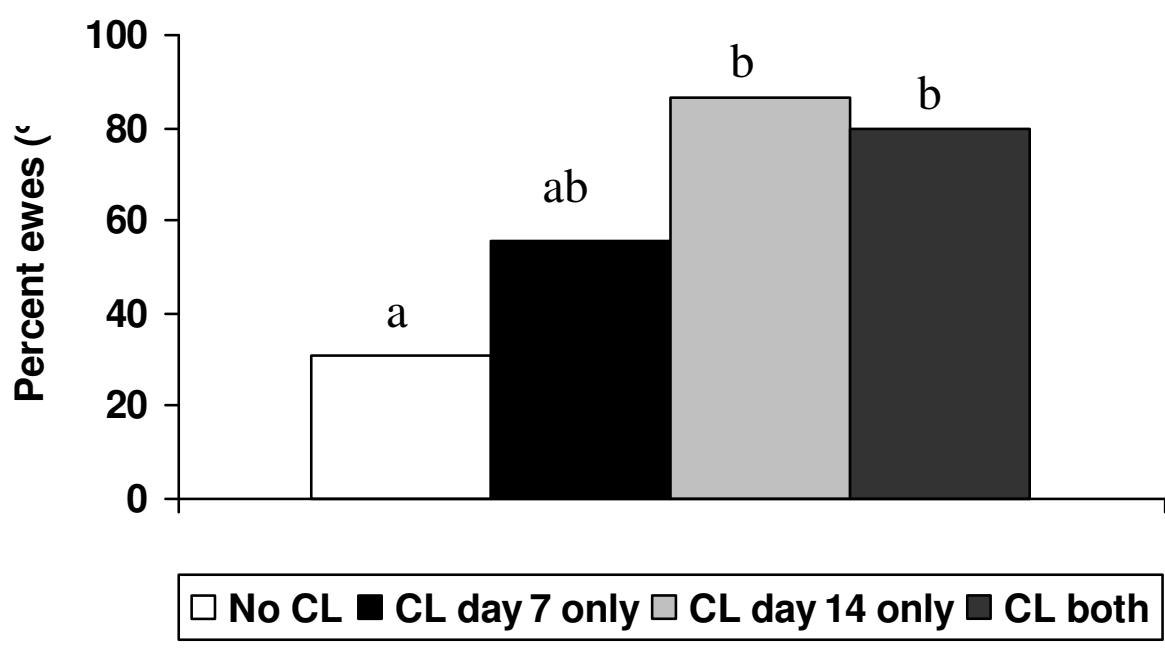


Figure 8. Percentage of ewes lambing overall in ewes in which a CL was detected on day 7 or 14 only, detected on both days, or not detected on either day (a,b: $p=0.01$ ).

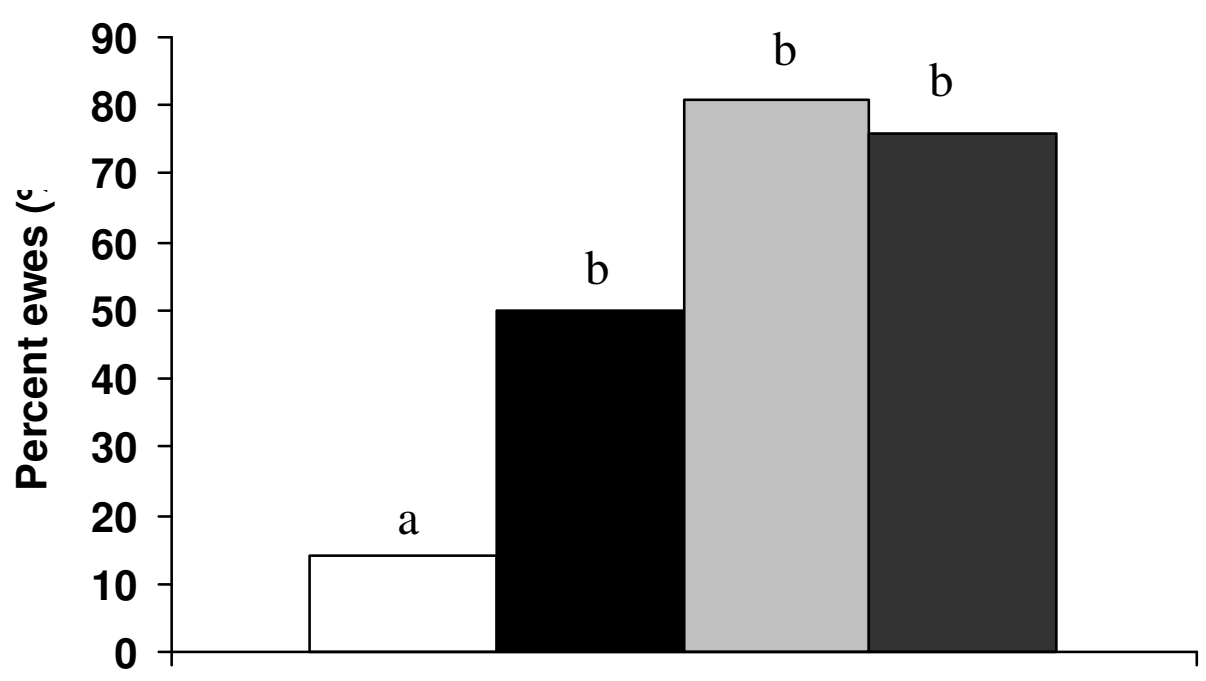

$\square$ No CL $\square$ CL day 7 only $\square$ CL day 14 only $\square$ CL both 
B. Mean concentrations of $\mathrm{P}_{4}$ for each treatment group in Experiment $2 \mathrm{~B}$ are presented in Figure 9. In ewes whose only treatment was introduction of rams or that received a single injection of GnRH 4 days before introduction of rams, mean concentrations of $\mathrm{P}_{4}$ remained less than $1 \mathrm{ng} / \mathrm{mL}$ until day 5, after which they rose steadily until treatment with $\mathrm{PGF}_{2} \alpha$. In ewes that received GnRH 4 days before and 1 day after introduction of rams, mean concentrations of $\mathrm{P}_{4}$ rose above $1 \mathrm{ng} / \mathrm{mL}$ on day 1 and continued to rise quickly until day 9 . In ewes that received a single injection of $\mathrm{P}_{4}$ at the time of introduction of rams, mean concentrations of $\mathrm{P}_{4}$ rose temporarily on day 1 and then declined and remained below $1 \mathrm{ng} / \mathrm{mL}$ until day 7 . After day 7 the mean concentration of $\mathrm{P}_{4}$ rose steadily, similar to concentrations of $\mathrm{P}_{4}$ in ewes whose only treatment was introduction of rams or that received a single injection of $\mathrm{GnRH} 4$ days before introduction of rams. The mean concentrations of $\mathrm{P}_{4}$ prior to introduction of rams were not greater than $1 \mathrm{ng} / \mathrm{mL}$ in any group (data not shown).

Ewes with a mean concentration of $\mathrm{P}_{4}>1 \mathrm{ng} / \mathrm{mL}$ were considered to have formed a CL (Figure 10). On the day of introduction of rams, there was no difference among groups in the percentage of ewes with $\mathrm{P}_{4}>1 \mathrm{ng} / \mathrm{mL}$. On day 7 , the percentage of ewes that had $\mathrm{P}_{4}>1 \mathrm{ng} / \mathrm{mL}$ was greater in treated ewes $\left(\mathrm{GnRH}\right.$ and $\left.\mathrm{P}_{4}\right)$ than in control ewes $(\mathrm{p}$ $<0.07$ ). On days 11 and 12 (data combined), there was again no difference among groups in the percentage of ewes that had high $\mathrm{P}_{4}$.

The percentages of ewes marked by rams after treatment with $\mathrm{PGF}_{2} \alpha$ and pregnant 95 days later tended to be greater ( $\mathrm{p}=0.08$ and 0.06 , respectively) in those ewes that received either 1 or 2 injections of $\mathrm{GnRH}$ or a single injection of $\mathrm{P}_{4}$ than in those that were only exposed to rams (53.2 vs. $28.6 \%$ and 73 vs. $50 \%$, for each variable 
respectively). Estrous response rates and ewes pregnant 95 days after treatment with $\mathrm{PGF}_{2} \alpha$ did not differ between ewes treated with $\mathrm{GnRH}$ or $\mathrm{P}_{4}$ or between ewes treated with GnRH 4 days before introduction of rams or 4 days before and 1 day after introduction of rams. Percentages of ewes with a detectable CL on day 11 after introduction of rams (78.8\%), pregnant 22 days after treatment with $\mathrm{PGF}_{2} \alpha(31.0 \%)$, and lambing (72\%) did not differ among treatment groups. Means for each treatment group are given in Table 4. 
Figure 9. Concentrations of $\mathrm{P}_{4}$ following introduction of rams in ewes that were introduced to rams alone, that were injected with GnRH 4 days before introduction of rams, that were injected with GnRH 4 days before and 1 day after introduction of rams, or that were injected with $\mathrm{P}_{4}$ at the time of introduction of rams
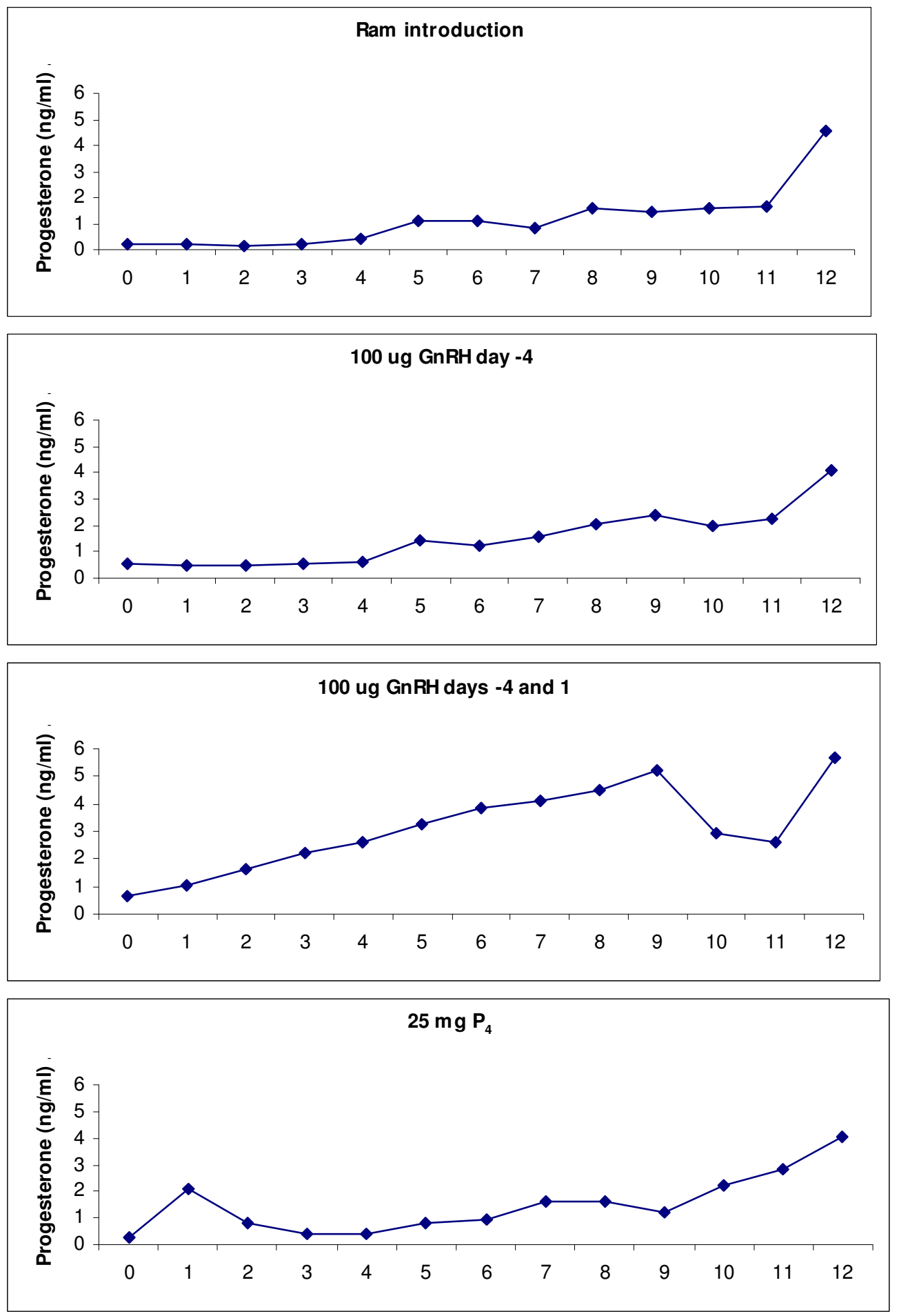

Day relative to introduction of rams 
Figure 10. Percentages of ewes with concentrations of $P_{4}>1 \mathrm{ng} / \mathrm{mL}$ following introduction of rams in ewes that were introduced to rams alone, that were injected with GnRH 4 days before introduction of rams, that were injected with GnRH 4 days before and 1 day after introduction of rams, or that were injected with $\mathrm{P}_{4}$ at the time of introduction of rams

a,b: $\mathrm{p}<0.07$

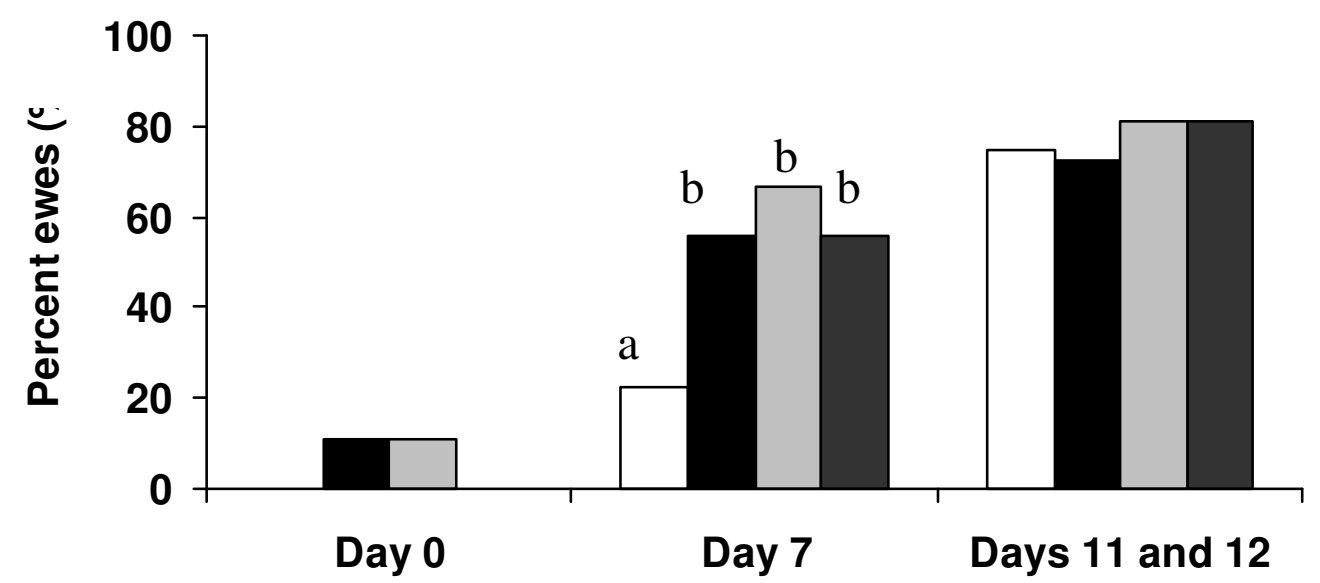

Ram introduction $\square$ GnRH day $-4 \square$ GnRH days -4 and $1 \square$ P4 
Table 4. Effect of time of treatment with $\mathrm{GnRH}$ or $\mathrm{P}_{4}$ on estrous response, formation of CL, pregnancy rates, ewes lambing of ewes treated, and days from $\mathrm{PGF}_{2} \alpha$ to lambing

\begin{tabular}{|c|c|c|c|c|}
\hline \multirow[t]{2}{*}{ Variable } & \multicolumn{4}{|c|}{ Treatment } \\
\hline & $\begin{array}{l}\text { Introduction } \\
\text { of rams }\end{array}$ & $\begin{array}{c}100 \mu g \text { GnRH } \\
\text { day }-4 \\
\end{array}$ & $\begin{array}{l}100 \mu \mathrm{g} \text { GnRH } \\
\text { days }-4 \text { and } 1\end{array}$ & $\begin{array}{c}25 \mathrm{mg} \\
\mathrm{P}_{4}\end{array}$ \\
\hline $\mathbf{N}$ & 21 & 22 & 21 & 21 \\
\hline $\begin{array}{l}\text { Percentage of ewes with } \\
\text { detectable CL on day } 11\end{array}$ & $\begin{array}{c}76.2 \\
(16 / 21)\end{array}$ & $\begin{array}{c}72.7 \\
(16 / 22)\end{array}$ & $\begin{array}{c}90.5 \\
(19 / 21)\end{array}$ & $\begin{array}{c}76.2 \\
(16 / 21)\end{array}$ \\
\hline $\begin{array}{l}\text { Percentage of ewes that } \\
\text { exhibited estrus a,x }\end{array}$ & $\begin{array}{l}28.6 \\
(6 / 21)\end{array}$ & $\begin{array}{c}50.0 \\
(11 / 22)\end{array}$ & $\begin{array}{c}52.4 \\
(11 / 21)\end{array}$ & $\begin{array}{c}57.1 \\
(12 / 21)\end{array}$ \\
\hline $\begin{array}{l}\text { Percentage of ewes pregnant } \\
\text { on day } 22 \text { after induced } \\
\text { estrus }\end{array}$ & $\begin{array}{c}19.1 \\
(4 / 21)\end{array}$ & $\begin{array}{l}28.6 \\
(6 / 22)\end{array}$ & $\begin{array}{c}38.1 \\
(8 / 21)\end{array}$ & $\begin{array}{c}38.1 \\
(8 / 21)\end{array}$ \\
\hline $\begin{array}{l}\text { Percentage of ewes pregnant } \\
\text { on day } 95 \text { after induced } \\
\text { estrus }{ }^{y}\end{array}$ & $\begin{array}{c}50.0 \\
(10 / 21)\end{array}$ & $\begin{array}{c}76.2 \\
(16 / 22)\end{array}$ & $\begin{array}{c}71.4 \\
(15 / 21)\end{array}$ & $\begin{array}{c}71.4 \\
(15 / 21)\end{array}$ \\
\hline $\begin{array}{l}\text { Percentage of ewes that } \\
\text { lambed to service } 1\end{array}$ & $\begin{array}{l}23.8 \\
(5 / 21)\end{array}$ & $\begin{array}{c}36.4 \\
(8 / 22)\end{array}$ & $\begin{array}{c}38.1 \\
(8 / 21)\end{array}$ & $\begin{array}{c}38.1 \\
(8 / 21)\end{array}$ \\
\hline $\begin{array}{l}\text { Percentage of ewes that } \\
\text { lambed to service } 2\end{array}$ & $\begin{array}{l}37.5 \\
(6 / 16)\end{array}$ & $\begin{array}{c}28.6 \\
(4 / 14)\end{array}$ & $\begin{array}{c}46.2 \\
(6 / 13)\end{array}$ & $\begin{array}{l}38.5 \\
(5 / 13)\end{array}$ \\
\hline $\begin{array}{l}\text { Percentage of ewes that } \\
\text { lambed to service } 3\end{array}$ & $\begin{array}{l}30.0 \\
(3 / 10)\end{array}$ & $\begin{array}{l}50.0 \\
(5 / 10)\end{array}$ & $\begin{array}{l}42.9 \\
(3 / 7)\end{array}$ & $\begin{array}{l}12.5 \\
(1 / 8)\end{array}$ \\
\hline $\begin{array}{l}\text { Percentage of ewes that } \\
\text { lambed overall }\end{array}$ & $\begin{array}{c}66.7 \\
(14 / 21)\end{array}$ & $\begin{array}{c}77.3 \\
(17 / 22)\end{array}$ & $\begin{array}{c}81.0 \\
(17 / 21)\end{array}$ & $\begin{array}{c}66.7 \\
(14 / 21)\end{array}$ \\
\hline Days from PGF to lambing & 170 & 169 & 166 & 160 \\
\hline
\end{tabular}




\section{Experiment 3}

Concentrations of melatonin in control and melatonin-implanted ewes on the day of implantation (day 0), and 35 and 49 days after implantation are shown in Figure 11. Concentrations of melatonin tended to be higher in ewes implanted with melatonin than in control ewes on days 35 and 49 after implantation $(p=0.10)$. In ewes implanted with melatonin, concentrations of melatonin were greater on days $35(\mathrm{p}=0.05)$ and $49(\mathrm{p}=$ 0.06) compared to day 0 . Percentages of ewes in each treatment group with concentrations of $\mathrm{P}_{4}>1 \mathrm{ng} / \mathrm{mL}$ on days 0,35 , and 49 (Figure 12) were affected by day (p $<0.0001)$, lactational status $(\mathrm{p}<0.0001)$, treatment with melatonin $(\mathrm{p}<0.002)$, day $\mathrm{x}$ lactational status $(\mathrm{p}<0.0001)$, day $\mathrm{x}$ treatment with melatonin $(\mathrm{p}<0.05)$, and lactational status $\mathrm{x}$ treatment with melatonin $(\mathrm{p}<0.05)$. Percentages of ewes with CL by day 49 were higher than days 0 and 35 (18.8 vs 3.2 and 5.1\%), in non-lactating than lactating ewes (18.2 vs. $2.2 \%$ ), and in melatonin-treated than non-treated ewes (13.7 vs. $6.5 \%)$. On day 49 , but not day 35 , more non-lactating than lactating ewes (37.3 vs. $3.7 \%$ ) and more melatonin-treated ewes than non-treated ewes had formed CL (29.3 vs. 12.4\%).

The percentage of ewes lambing was lower $(\mathrm{P}=0.03)$ in control ewes that were only exposed to rams $(5.8 \%)$ than in ewes that were implanted with melatonin 35 days before introduction of rams (15.8\%; Figure 13). There was no difference in the percentage of ewes lambing between lactating (9.8\%) and dry ewes (11.75\%) and there was no interaction between lactation and melatonin treatment. Means for each treatment group are given in Table 5. 
Figure 11. Concentrations of melatonin in ewes implanted with melatonin and control ewes on days 0,35 , and 49 after implantation

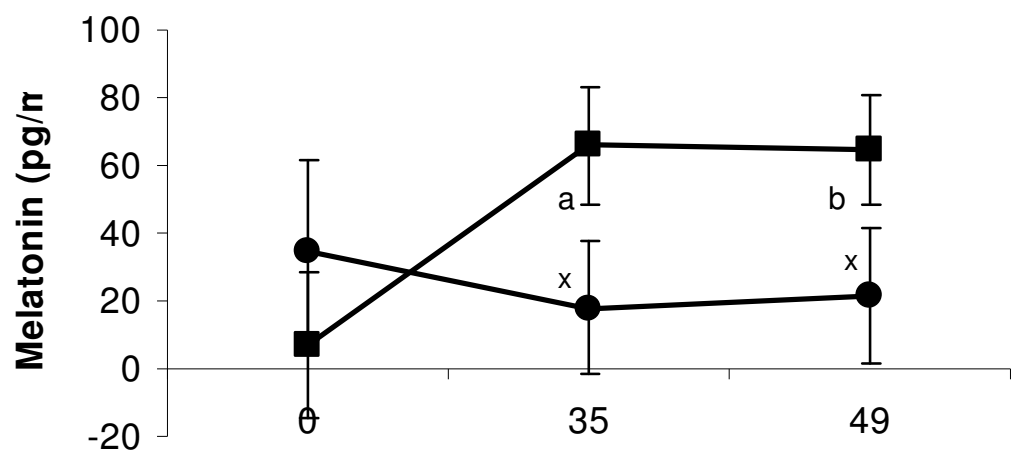

Day relative to implantation of melatonin

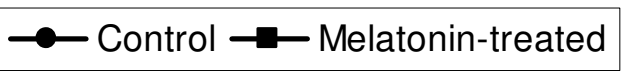

a: melatonin-treated day 0 vs. day $35, \mathrm{p}=0.05$

b: melatonin-treated day 0 vs. day 49, $\mathrm{p}=0.06$

x: melatonin-treated vs. control day 35 and melatonin-treated vs. control day $49, p=0.10$ 
Figure 12. Effect of lactational status, melatonin treatment, and day relative to implantation on percentages of ewes with concentrations of $P_{4}>1 \mathrm{ng} / \mathrm{mL}$

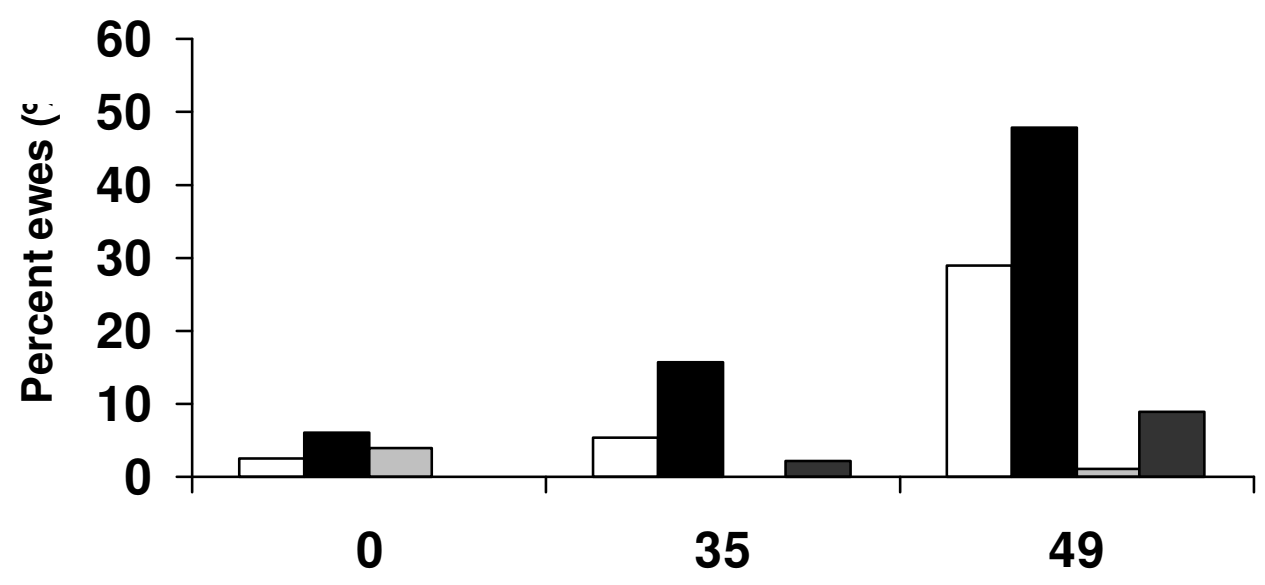

Day relative to implantation of melatonin

\begin{tabular}{|ll|}
\hline$\square$ Dry control & Dry melatonin-treated \\
$\square$ Lactating control & $\square$ Lactating melatonin-treated \\
\hline
\end{tabular}

Lactational status: $\mathrm{p}<0.0001$

Melatonin treatment: $\mathrm{p}<0.002$

Day relative to implantation: $\mathrm{p}<0.0001$

Day relative to implantation $\mathrm{x}$ Lactational status: $\mathrm{p}<0.0001$

Day relative to implantation $x$ Melatonin treatment: $p<0.05$

Lactational status $\mathrm{x}$ Melatonin treatment: $\mathrm{p}<0.05$ 
Figure 13. Effect of melatonin treatment on percentages of ewes lambing overall $a, b: p=0.03$

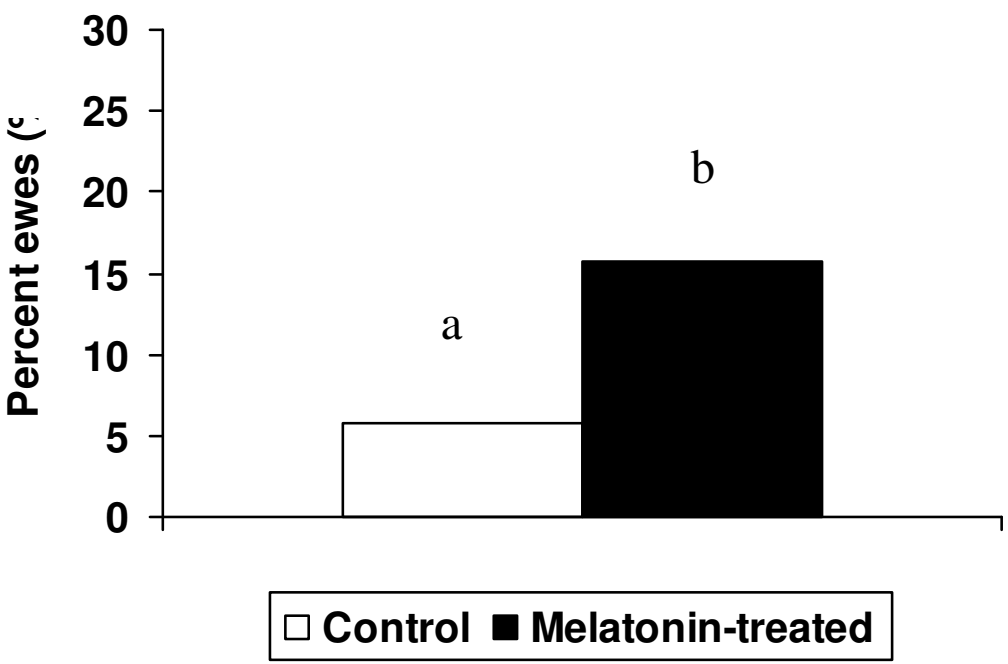


Table 5. Effect of lactational status and melatonin treatment on percentages of ewes lambing overall

\begin{tabular}{lcccc}
\hline \multicolumn{1}{c}{ Variable } & \multicolumn{4}{c}{ Treatment } \\
\hline & $\begin{array}{c}\text { Dry } \\
\text { Control }\end{array}$ & $\begin{array}{c}\text { Dry } \\
\text { Melatonin-treated }\end{array}$ & $\begin{array}{c}\text { Lactating } \\
\text { Control }\end{array}$ & $\begin{array}{c}\text { Lactating } \\
\text { Melatonin-treated }\end{array}$ \\
\hline $\mathbf{N}$ & 65 & 52 & 95 & 49 \\
\hline Percentage of & 6.2 & 17.3 & 5.3 & 14.3 \\
ewes lambing $^{\text {a }}$ & $(4 / 65)$ & $(9 / 52)$ & $(5 / 95)$ & $(7 / 49)$ \\
\hline
\end{tabular}

${ }^{a}$ Melatonin implanted vs. control ewes, $p=0.03$ 


\section{Discussion}

In experiment 1, ewes were treated with GnRH 2 days (48 hours) after treatment with $\mathrm{P}_{4}$ and introduction of rams in an attempt to increase the number of ewes with a functional $\mathrm{CL}$ on day 14 when $\mathrm{PGF}_{2} \alpha$ was used to induce luteolysis. Treatment with GnRH increased the percentage of ewes forming CL in response to introduction of rams numerically (17\%), but not significantly. Similarly, treatment with GnRH on day 2 did not alter estrous response, pregnancy rate, or percentage of ewes lambing. The lack of effect of treatment with GnRH on the percentage of ewes with CL is probably related to the high percentage of control ewes that formed CL in this study. The percentage of ewes ovulating in response to introduction of rams is variable and is affected by a number of factors including the depth of anestrus at the time of introduction. In the present experiment, rams were introduced in mid-June, well past the period of deepest anestrus in May. Additionally, some ewes were possibly cycling prior to the commencement of the experiment. Interestingly, almost all ewes treated with GnRH had CL after introduction of rams. The lack of difference here does not preclude the face that treatment with GnRH may be beneficial under conditions when the introduction of rams alone is not sufficient to induce ovulation in a large percentage of anestrous ewes.

In experiment 1 , there were no differences in estrous response and the percentages of ewes pregnant and lambing between treated and non-treated ewes. It is well documented that pre-exposure to $\mathrm{P}_{4}$ is necessary for physiological concentrations of $\mathrm{E}_{2}$ to induce estrous behavior in anestrous ewes. Thus, it is not expected that percentages of ewes showing behavioral estrus would be different. Despite a high ovulatory response 
rate in both treated and non-treated ewes, which were scanned for the presence of CL on Farm 2, the overall lambing rate appears to be low. The percentages of ewes on Farm 2 in which a CL was detected on day $14(84.1 \%)$ and which were pregnant and lambed (62.2\%) reveal that the poor reproductive performance observed for all ewes in the experiment can be attributed to the results obtained from Farm 1. Indeed, there was a significant effect of farm on the percentage of ewes pregnant and lambing. The difference between the results obtained from the two farms might be attributed to breed differences as there was a higher percentage of purebred Suffolks, which are considered to have very short breeding seasons and tend to show a low response to out-of-season breeding protocols, on Farm 1 (M. Knights, personal communication; Notter et al., 1992). Additionally, the differences between the two farms may be attributed to differences in the rams used as rams did not undergo breeding soundness exams before commencement of the study. Data from out-of-season breeding studies done on Farm 1 in previous years show consistently poor reproductive performance following treatments designed to interrupt anestrus.

In experiment $2 \mathrm{~A}$, ewes were treated with $\mathrm{GnRH}$ at two time periods. Gonadotropin-releasing hormone was injected 2 days after introduction of rams in an attempt to increase the percentage of ewes ovulating immediately after introduction of rams. Some ewes were injected 7 days after introduction of rams in an attempt to increase the percentage of ewes that might reovulate after premature regression of the CL resulting from the first ram-induced ovulation.

The percentages of ewes with a detectable CL on day 7 only, 14 only, both days, or neither day did not differ among treatment groups. It was anticipated that injections of 
GnRH on both days 2 and 7 would increase the percentage of ewes with a CL on day 14 due to the combined effect of having more ewes ovulating in response to rams and forming functional CL thus more ewes would be exposed to a period of $\mathrm{P}_{4}$ from a shortlived CL, which would support the viability of the CL formed from the second ovulation. While a direct comparison with ewes not treated with $\mathrm{GnRH}$ cannot be made in this study, similar percentages of ewes with detectable CL on day 7 in ewes which had been treated up to that point (groups GnRH day 2 and GnRH both; 48.7\%) and ewes that had not yet received treatment with GnRH (group GnRH 7; 44.4\%) indicate that treatment with GnRH did not affect the ovulatory response following introduction of rams.

The lack of differences in ovulatory response rates among ewes treated with GnRH 2, 7, or both days after introduction of rams may be attributed to an inadequate dosage of GnRH $(100 \mu \mathrm{g})$ injected to ewes in this study. In the cow during postpartum anestrus, 200 but not 25,50,75, or $100 \mu \mathrm{g}$ increased pregnancy and conception rates and reduced intervals to first ovulation and first detected estrus (Benmrad and Stevenson, 1986; Stevenson and Call, 1988; Chenault, 1990). Studies on GnRH dosages in sheep provide conflicting results. Restall and Radford (1974) found that treatment of lactating ewes with $50 \mu \mathrm{g}$ GnRH resulted in release of $\mathrm{LH}$ and ovulation in 50 to $70 \%$ of treated ewes. However, Lopez-Sebastian and colleagues (1984) found that treatment with $50 \mu \mathrm{g}$ $\mathrm{GnRH}$ at the time of introduction of rams did not increase plasma $\mathrm{P}_{4}$ concentrations, lambing rates, or interval from treatment to lambing in anestrous ewes compared to ewes whose only treatment was introduction of rams. Crighton and colleagues (1973) and Haresign and colleagues (1975) found that treatment with $150 \mu \mathrm{g} \mathrm{GnRH}$ induced ovulation in almost all treated anestrous ewes. Additional studies are needed to elucidate 
the dose of GnRH that is optimally effective to induce anestrous ewes to ovulate. Another cause for the lack of difference between ewes treated with GnRH 2, 7, or both days after introduction of rams might be improper timing of the first injection of GnRH. The lack of effect of treatment with GnRH might be affected by the timing of the GnRH injection. Martin and colleagues (1986) observed that the period from introduction of rams to the LH surge is approximately 18 to 36 hours and that most ewes ovulate within 50 hours of introduction of rams. This indicates a period of time from the LH surge to ovulation of 27 to 27 hours. Crighton and colleagues (1973) and Haresign and colleagues (1975) found that administration of GnRH to anestrous ewes resulted in an LH surge approximately 2 hours after treatment. In the present experiment, GnRH was injected 48 hours after introduction of rams but these ewes were not pretreated with $\mathrm{P}_{4}$, which delays the onset of the LH surge to 60 hours (Pearce et al., 1985), and so the injection of GnRH 2 days after introduction of rams might have been too late.

Because of the variety of luteal outcomes possible when anestrous ewes are treated with GnRH, the ewes were reclassified based on the presence or absence of a detectable CL on day 7 and 14. The percentage of ewes with a CL on day 7, 14, both days, or neither day did not differ among treatment groups. Ewes with a detectable CL on day 14 had a higher percentage showing estrus and lambing than ewes that didn't have a CL on either day. Interestingly, ewes with a CL on day 7 only showed the same estrous response rate and percentage of ewes lambing of ewes treated as those that had a CL on day 14. These ewes most likely had a slightly shortened luteal phase, meaning they had a CL which regressed just prior to day 14 , or was regressing at that time and could not be visualized by ultrasonography. 
In the previous experiments, treatment with GnRH 2 days after introduction of rams did not enhance the ovulatory response in anestrous ewes pretreated with (Experiment 1) or not pretreated with $\mathrm{P}_{4}$ (Experiment 2A) at the time of introduction of rams. However, GnRH may act as insurance against a low ovulatory response when introduction of rams alone would yield a poor response. In Experiment 2B, the ovulatory response of anestrous ewes exposed to rams was studied to evaluate the effects of GnRH given at strategic time points deemed more physiologically appropriate than those used in Experiment 1 and 2A. The first treatment with GnRH given 4 days before introduction of rams was aimed at inducing ovulation or luteinization to provide an endogenous source of $\mathrm{P}_{4}$. The second treatment with GnRH given 1 day after introduction of rams was aimed at increasing the ovulatory response following introduction of rams, while the combined treatment was aimed at allowing a higher proportion of ewes to develop a fully functional CL with a normal lifespan.

A detectable rise in $\mathrm{P}_{4}$ was not observed prior to introduction of rams in any treatment group, which indicated that the initial GnRH injection at day -4 was not effective at inducing ovulation or luteinization before introduction of rams. However, it is more likely that the magnitude and duration of secretion of $\mathrm{P}_{4}$ was not sufficient to be detected in the assay. Treatment with GnRH 4 days before introduction of rams did not alter the pattern of secretion of $\mathrm{P}_{4}$ after rams were introduced from that observed in ewes introduced to rams alone, a significant rise ( $>1 \mathrm{ng} / \mathrm{mL}$ ) commenced on day 5 . In ewes that were injected with $\mathrm{P}_{4}$ at the time of introduction of rams, an initial rise associated with the injection of $\mathrm{P}_{4}$ was detected on day 1 , followed by a decline on day 2 . The postovulatory rise in $\mathrm{P}_{4}$-treated ewes was delayed until day 6 or 7 , presumably due to a delay 
in the ram-induced LH surge as observed by Pearce and colleagues (1985). In contrast to the other groups, the concentration of $\mathrm{P}_{4}$ in ewes treated with $\mathrm{GnRH} 4$ days before and 1 day after introduction of rams rose above $1 \mathrm{ng} / \mathrm{mL}$ on day 1 and continued to rise until day 9. This pattern of secretion is evidence of having achieved the goal of the combined treatment, namely an increase in the percentage of ewes ovulating following introduction of rams due to the injection of GnRH on day 1 and protection of the CL resulting from that ovulation due to the effects of $\mathrm{P}_{4}$ produced as a result of ovulation or luteinization caused by the injection of GnRH 4 days before introduction of rams. The overall percentage of ewes with a detectable CL 11 days after introduction of rams was high (78.8\%) and precluded the detection of any significant differences among treatment groups despite that 10-18\% more ewes treated with GnRH 4 days before and 1 day after introduction of rams had a detectable CL.

Based on the findings of Experiments 1 and 2, treatment with GnRH 2 days after introduction of rams, with or without $\mathrm{P}_{4}$ pretreatment, did not improve the percentage of ewes ovulating in response to introduction of rams. Treatment 1 day after introduction of rams was able to elicit this response. However, pretreatment with GnRH 4 days before, in addition to treatment 1 day after, introduction of rams did not result in more ewes lambing. Each of these treatments resulted in percentages of ewes ovulating, pregnant, and lambing similar to those obtained with $\mathrm{P}_{4}$ pretreatment alone, indicating that $\mathrm{GnRH}$ given at the appropriate time may be able to replace $\mathrm{P}_{4}$ in out-of-season breeding approaches.

The percentages of ewes marked by rams after treatment with $\mathrm{PGF}_{2} \alpha$ and pregnant 95 days after induced estrus were greater among treated $\left(\mathrm{GnRH}\right.$ and $\left.\mathrm{P}_{4}\right)$ than 
non-treated ewes. However, there were no differences between ewes treated with GnRH at different times or between ewes treated with $\mathrm{GnRH}$ and ewes treated with $\mathrm{P}_{4}$. Thus, GnRH was not less effective than $\mathrm{P}_{4}$ to enable breeding of anestrous ewes. This is an important finding, as $\mathrm{GnRH}$ is more available to producers than $\mathrm{P}_{4}$. The lack of differences among treatment groups for all variables tested except estrous response and pregnancy rates might be attributed to small sample sizes and a higher than expected percentage of control ewes that were already ovulating or responded to introduction of rams. In early May, before commencement of the experiment, blood samples were taken and assayed for concentrations of $\mathrm{P}_{4}$ to identify animals that were cycling or already pregnant and these animals were not used in the study. However, treatment with $\mathrm{PGF}_{2} \alpha$ did not occur until late June, more than a month after the initial blood samples were taken. Some of the ewes on the study likely began cycling during that time, as May is generally thought to be the deepest part of anestrous. Further adding to the likelihood that ewes may have begun cycling between May and June is the fact that the ewes on the study were mostly 50 to $75 \%$ Katahdin, a hair breed known for its ability to breed throughout the year and that the Katahdin breeding had been introduced into a flock already selected somewhat for ability to breed in June.

The ovulatory response following introduction of rams to anestrous ewes is generally lower in lactating than in non-lactating ewes and during the anestrous period than during the transition into the breeding season. Experiment 3 examined the effect of treatment with melatonin on the ovulatory response of anestrous ewes to introduction of rams, and whether the effect of melatonin was modified by lactational status. Ewes implanted with melatonin maintained higher serum concentrations of melatonin 35 and 
49 days after implantation compared to the day of implantation. However, the mean concentrations of melatonin 35 and 49 days after implantation only tended to be higher in implanted ewes than in corresponding control ewes. Large standard errors indicated high variability in the concentrations of melatonin achieved 35 and 49 days after implantation. Further, the melatonin concentrations in implanted ewes observed 35 and 49 days after implantation were much lower than those observed in similarly treated ewes in other experiments. O'Callaghan et al. (1991) inserted $700 \mathrm{mg}$ subcutaneous implants in ewes kept on an intermediate photoperiod and found that daytime melatonin concentrations were approximately $100 \mathrm{pg} / \mathrm{mL} 29$ days after implantation. Ronayne et al. (1989) inserted the same implants to anestrous ewes and found that daytime melatonin concentrations were $141 \mathrm{pg} / \mathrm{mL} 30$ days after implantation. An interesting possibility presented by these two studies is that melatonin concentrations in the current experiment may have reached levels over $100 \mathrm{pg} / \mathrm{mL}$ and then dropped before the first postimplantation blood sample was taken on day 35. However, this seems unlikely as concentrations of melatonin remained stable from days 35 to 49 after implantation. In addition to a time factor, these studies used $700 \mathrm{mg}$ implants while the present experiment used $18 \mathrm{mg}$ implants, which may account for the lower melatonin concentrations. While the authors didn't measure melatonin concentrations, Stellflug et al. (1988) used the same $18 \mathrm{mg}$ implants in spring-mated ewes as were used in the present experiment, but inserted new implants every 10 days citing evidence that the implants have been shown to maintain plasma concentrations of melatonin above 232 $\mathrm{pg} / \mathrm{mL}$ for 10 days. These studies indicate that higher concentration implants or more 
frequent insertion of lower concentration implants would have resulted in higher circulating melatonin concentrations in the present experiment.

Ovulatory response 35 days after melatonin implantation, measured by percentage of ewes with $\mathrm{P}_{4}$ concentrations $>1 \mathrm{ng} / \mathrm{mL}$, can be attributed to the effects of melatonin and lactation alone, as these blood samples were taken before treatment with $\mathrm{P}_{4}$ and introduction of rams. The difference between the number of ewes cycling on days 0 and 35 was greatest in dry ewes which were treated with melatonin and more of these ewes had ovulated by day 35 than any other group, indicating that melatonin treatment alone is capable of inducing dry ewes to cycle during anestrus. Between days 35 and 49, the change in the percentage of ewes cycling in dry ewes not treated with melatonin was $23.7 \%$, compared to $32.2 \%$ in dry ewes treated with melatonin. These data indicated that there was an interaction between lactational status and melatonin treatment. Treatment with melatonin increases the abilities of anestrous ewes to respond to introduction of rams, but the magnitude of the effect is greater in non-lactating than in lactating ewes.

Although treatment with melatonin did affect the percentage of dry ewes with high $\mathrm{P}_{4}$, some evidence indicates that an even greater response could be observed after a longer duration of time following melatonin implantation. For example, Ronayne et al. (1989) found that the first time at which $\mathrm{P}_{4}$ concentrations in implanted ewes were higher $(\mathrm{p}<0.01)$ than in control ewes occurred 66 days after implantation. However, this delayed response to melatonin was observed in Cheviot and Suffolk ewes, both of which are known for their short breeding seasons and decreased ability to respond to out-ofseason breeding approaches. 
Although the percentages of ewes lambing were higher in ewes that were implanted than in control ewes in the present study, both groups had lower percentages of ewes lambing than ewes from previous studies using the same implants. Stellflug et al. (1988) reported that 54\% of control ewes lambed, $58 \%$ of ewes implanted with melatonin for 20 days before breeding lambed, and $75 \%$ of ewes implanted with melatonin for 40 days before breeding lambed when the implants were changed every 10 days. As discussed previously, the increased frequency of melatonin implantation may have led to higher circulating melatonin concentrations, resulting in increased ability of the ewes treated with melatonin to resume cyclicity. Additionally, breed differences may account for lowered percentages of ewes lambing in all groups. Stellflug et al. (1988) utilized Polypay and Polypay cross ewes in their study. The Polypay breed is a composite of the Dorset, Rambouillet, Finnsheep, and Targhee breeds, all of which have been recognized for their extended breeding seasons and ability to lamb more than once per year.

While the ability of anestrous ewes to respond to introduction of rams is improved by treatment with melatonin, the magnitude of this improvement appears to be affected by the concentration of melatonin contained in the implant, the frequency with which the implant is inserted, the breed of the ewes being treated, and the duration of time between melatonin treatment and introduction of rams. 


\section{Summary}

Inducing ewes to breed more frequently than once per year allows producers to reduce the maintenance costs per offspring reared, increase net return, increase production per dollar of capital investment, provide a more uniform supply of lamb throughout the year, and take advantage of higher and more stable prices for their products.

Most approaches to breeding ewes more than once per year involve the introduction of rams during the anestrus period. This approach yields variable and generally poor results dependent on the stage of anestrus and lactation and nutritional status. The present studies were conducted with the aim of developing protocols using $\mathrm{GnRH}$ and melatonin in conjunction with the introduction of rams to increase the percentage of anestrous ewes that ovulate, exhibit estrus, conceive, and lamb.

Treatment with GnRH at various times around introduction of rams consistently resulted in a high ovulatory response but did not improve the overall reproductive performance over that obtained by the introduction of rams alone. Higher than expected percentages of ewes ovulated after the introduction of rams alone, probably due to the season when the experiments were conducted and the genetics of the ewes. Further studies conducted closer to the deepest part of anestrus and using more experimental animals are needed to make any significant conclusions on the value of treatment with GnRH in out-of-season breeding protocols.

Treatment with melatonin increased the ovulatory and reproductive performance of anestrous ewes exposed to rams. However, responses to introduction of rams were less than those observed when treatment was given during the transition into the breeding 
season. Further studies, possibly using different potencies, frequencies, and durations of melatonin implantation, are warranted to determine if treatment with melatonin can increase the response of anestrous ewes to introduction of rams to a level similar to that observed during the transition into the breeding season. 


\section{Literature Cited}

Ahmad, N., Lewis, P.E., Walker, C.Z., Alt, F.L., and Inskeep, E.K. 1996. FSH in propylene glycol on ovulation rate and prolificacy in anestrous ewes. J. Anim. Sci. 74 (Suppl. 1), 212.

Al-Shorepy, S.A., and Notter, D.R. 1996. Genetic variation and covariation for ewe reproduction, lamb growth, and lamb scrotal circumference in a fall-lambing sheep flock. J. Anim. Sci. 74, 1490-1498.

Asdell SA. 1964. Patterns of Mammalian Reproduction. Cornell University Press, Ithaca, New York.

Atkinson, S., and Williamson, P. 1985. Ram-induced growth of ovarian follicles and gonadotropin inhibition in anoestrous ewes. J. Reprod. Fert. 73, 185-189.

Bartlewski, P.M., Beard, A.P., Chapman, C.L., Nelson, M.L., Palmer, B., Aravindakshan, J., Cook, S.J., and Rawlings, N.C. 2001. Ovarian responses in gonadotrophin-releasing hormone-treated anoestrous ewes: follicular and endocrine correlates with lueal outcome. Reprod. Fertil. Dev. 13, 133-142.

Bazer, F.W. and First, N.L. 1983. Pregnancy and parturition. J. Anim. Sci. 57 (Suppl. 2), 425-431.

Benmrad, M., and Stevenson, J.S. 1986. Gonadotropin-releasing hormone and prostaglandin F2alpha for postpartum dairy cows: estrous, ovulation, and fertility traits. J. Dairy Sci. 69, 800-811.

Call, J.W., Foote, W.C., Eckre, C.D., and Hulet, C.V. 1976. Postpartum uterine and ovarian changes, and estrous behavior from lactation effects in normal and hormone treated ewes. Therio. 6, 495-501.

Carlson, C.D. 2000. The effect of melatonin dosage and progesterone on reproduction in anestrous ewes. California State University, Chico.

http://www.csuchico.edu/agr/tempDocs/ccarlson.html.

Chenault, J.R. 1990. Effect of fertirelin acetate or buserelin on conception rate at first or second insemination in lactating dairy cows. J. Dairy Sci. 73, 633-638.

Clarke, I.J., and Cummins, J.T. 1982. The temporal relationship between gonadotropin releasing hormone and luteinizing hormone secretion in ovariectomized ewes. Endocrin. $111,1737-1739$.

Cognie, Y., Hernandez-Barreto, M., and Saumande, J. 1975. Low fertility in nursing ewes during the non-breeding season. Annls. Biol. anim. Biochim. Biophys. 15, 329343. 
Cohen-Tannoudji, J., Lavenet, C., Locatelli, A., Tillet, Y., and Signoret, J.P. 1989. Noninvolvement of the accessory olfactory system in the LH response of anoestrous ewes to male odour. J. Reprod. Fert. 86, 135-144.

Cole, H.H., and Miller, R.F. 1935. Changes in the reproductive organs of the ewe with some data on their control. Am. J. Anat. 57, 39-97.

Coop, I.E. 1966. Effect of flushing on reproductive performance of ewes. J. Agric. Sci. 67, 305-323.

Crighton, D.B., Foster, J.P., Haresign, W., Haynes, N.B., and Lamming, G.E. 1973. The effects of a synthetic preparation of gonadotropin releasing factor on pituitary and ovarian function in anoestrous ewes. J. Physiol. 231, 98P-99P.

Cushwa, W.T., Bradford, G.E., Stabenfeldt, G.H., Berger, Y.M., and Dally, M.R. 1992. Ram influence on ovarian and sexual activity in anestrous ewes: Effects of isolation of ewes from rams before joining and date of ram introduction. J. Anim. Sci. 70, 11951200.

Ducker, M.J., and Bowman, J.C. 1970a. Photoperiodism in the ewe. 3. The effects of various patterns of increasing daylength on the onset of anoestrous in Clun Forest ewes. Anim. Prod. 12, 465-471.

Ducker, M.J., and Bowman, J.C. 1970b. Photoperiodism in the ewe. 4. A note on the effect of onset of oestrus in Clun Forest ewes of applying the same decrease in daylength at two different times of the year. Anim. Prod. 12, 513-516.

Ducker, M.J., and Bowman, J.C. 1972. Photoperiodism in the ewe. 5. An attempt to induce sheep of three breeds to lamb every eight months by artificial daylength changes in a non-light-proofed building. Anim. Prod. 14, 323-334.

Dutt, R.H. 1953. Induction of estrus and ovulation in anestrual ewes by use of progesterone and pregnant mare serum. J. Anim. Sci. 12, 515-523.

Dutt, R.H., and Casida, L.E. 1948. Alteration of the estrual cycle in sheep by use of progesterone and its effects upon subsequent ovulation and fertility. Endocrin. 43, 208217.

Dyrmundsson, O.R. 1973. Puberty and early reproductive performance in sheep. I. Ewe lambs. Anim. Abstr. 41, 273-289.

Fabre-Nys, C., and Martin, G.B. 1991. Roles of progesterone and oestradiol in determining the temporal sequence and quantitative expression of sexual receptivity and the preovulatory LH surge in the ewe. J. Endocrinol. 130, 367-379. 
Foote, W.C. 1971. Some influences of lactation and hormone treatment on uterine changes in postpartum sheep. J. Anim. Sci. 32 (Suppl 1), 48-54.

Ford, J.J. 1979. Postpartum reproductive performance of Finnsheep-Crossbred ewes. J. Anim. Sci. 49, 1043-1050.

Gilbert, R.O. 1999. Reproductive opportunities and challenges. College of Veterinary Medicine, Cornell University. Proceedings of the 1999 Winter Dairy Management Schools, p 75-83, Ithaca, NY.

Goodman, R.L. 1994. Neuroendocrine control of the ovine estrous cycle. Knobil, E. and Neill, J.D. The Physiology of Reproduction. $2^{\text {nd }}$ (47), 659-709. New York, Raven Press.

Gordon, I. 1997. Controlled reproduction in sheep and goats. Controlled reproduction in farm animals series, volume 2. CAB International. New York, NY.

Hafez, E.S.E. 1952. Studies on the breeding season and reproduction of the ewe. J. Agric. Sci. 42, 189-265.

Haresign, W., Foster, J.P., Haynes, N.B., Crighton, D.B., and Lamming, G.E. 1975. Progesterone levels following treatment of seasonally anoestrous ewes with synthetic LH-releasing hormone. J. Reprod. Fert. 43, 269-279.

Havern, R.L., Whisnant, C.S., and Goodman, R.L. 1994. Dopaminergic structures in the ovine hypothalamus mediating estradiol negative feedback in anestrous ewes. Endocrin. 134, 1905-1914.

Hulet, C.V., Shelton, M., Gallagher, J.R., and Price, D.A. 1974. Effects of origin and environment on reproductive phenomena in Rambouillet ewes. I. Breeding season and ovulation. J. Anim. Sci. 38, 1210-1217.

Hunter, M.G., Southee, J.A., McLeod, B.J., and Haresign, W. 1986. Progesterone pretreatment has a direct effect on GnRH-induced preovulatory follicles to determine their ability to develop into normal corpora lutea in anoestrous ewes. J. Reprod. Fert. 76, 349-363.

Hunter, M.G., Ayad, V.J., Gilbert, C.L. Southee, J.A., and Wathes, D.C. 1989. Role of prostaglandin $\mathrm{F}_{2 \alpha}$ and oxytocin in the regression of $\mathrm{GnRH}$-induced abnormal corpora lutea in anestrous ewes. J. Reprod. Fert. 85, 551-561.

Jordan, K.M., Wurst, A.K., Inskeep, E.K., and Knights, M. 2004. Effect of GnRH in conjunction with ram introduction on the induction of fertile estrus during the nonbreeding season. J. Anim. Sci. 82, Suppl. 1, 310. 
Karsch, F.J., Bittman, E.L., Foster, D.L., Goodman, R.L., Legan, S.J., and Robinson, J.E. 1984. Neuroendocrine basis of seasonal reproduction. Recent Prog. Hor. Res. 40, 185225.

Karsch, F.J., Dahl, G.E., Evans, N.P., Manning, J.M., Mayfield, K.P., Moenter, S.M., and Foster, D.L. 1993. Seasonal changes in gonadotropin-releasing hormone secretion in the ewe: Alteration in response to the negative feedback action of estradiol. Biol. Reprod. 49, 1377-1383.

Kieborz-Loos, K.R., Garverick, H.A., Keisler, D.H., Hamilton, S.A., Salfen, B.E., Youngquist, R.S., and Smith, M.F. 2003. Oxytocin-induced secretion of prostaglandin $\mathrm{F}_{2} \alpha$ in postpartum beef cows: Effects of progesterone and estradiol-17 $\beta$ treatment. J. Anim. Sci. 81, 1830-1836.

Kiesling, D.O., Akinbami, M.A., Meredith, S., and Warren, J.E. 2000. Uterine contraction patterns and fertility in early postpartum ewes. Small Rum. Res. 38, 51-56.

Knight, T.W. Peterson, A.J., and Payne, E. 1978. The ovarian and hormonal response of the ewe to stimulation by the ram early in the breeding season. Therio. 10, 343-348.

Knight, T.W., and Lynch, P.R. 1980. Source of ram pheromones that stimulate ovulation in the ewe. Anim. Reprod. Sci. 3, 133-136.

Knights, M. 2001. Induction of fertile estrus during seasonal anestrus in ewes and fall born ewe lambs. Doctoral Dissertation, West Virginia University, Division of Animal and Veterinary Sciences, Morgantown, WV.

Knights, M., Baptiste, Q.S., and Lewis, P.E. 2002. Ability of ram introduction to induce LH secretion, estrus, and ovulation in fall-born ewe lambs during anestrus. Anim. Reprod. Sci. 69, 199-209.

Knights, M., Singh-Knights, D., Bourne, G.A., Inskeep, E.K., and Lewis, P.E. 2004. Use of the ram effect to induce out of season breeding. $7^{\text {th }}$ World Sheep \& Wool Congress Conference Book. 355-377.

Kubasik, N.P., Hallauer, G.D, and Brodows, R.G. 1984. Evaluation of a direct solidphase radioimmunoassay for progesterone, useful for monitoring luteal function. Clin. Chem. 30, 284-286.

Lax, J., French, L.R., Chapman, A.B., Pope, A.L., and Casida, L.E. 1979. Length of breeding season for eight breed groups of sheep in Wisconsin. J. Anim. Sci. 49, 939942.

Lamb G.C. 2002. Review of estrous synchronization systems: GnRH. Proceedings: The Applied Reproductive Strategies Beef Cattle Workshop, p 23-32, Manhattan, KS. 
Legan, S.J., Karsch, F.J, and Foster, D.L. 1977. The endocrine control of seasonal reproductive function in the ewe: A marked change in response to the negative feedback action of estradiol on luteinizing hormone secretion. Endocrin. 101, 818-824.

Lopez-Sebastian, A., Gomez-Brunet, A., and Inskeep, E.K. 1984. Effects of a single injection of LHRH on the response of anestrous ewes to the introduction of rams. J. Anim. Sci. 59, 277-283.

Mallampati, R.S., Pope, A.L., and Casida, L.E. 1971. Breeding pattern in Targhee ewes and ewe lambs throughout the year. J. Anim. Sci. 32, 673-677.

Malpaux, B., Robinson, J.E., Wayne, N.L., and Karsch, F.J. 1989. Regulation of the onset of the breeding season of the ewe: Importance of long days and of an endogenous reproductive rhythm. J. Endocrin. 122, 269-278.

Manz, B., Seidel, A., Alexander, H., Wagner, B., Vollrath, L., Zimmermann, G., Wiedemann, K., and Pollow, K. 1989. Development and validation of a radioimmunoassay for serum melatonin. J. Clin. Chem. Clin. Biochem. 27, 797-802.

Marshall, F.H.A. 1937. On the change over in the oestrous cycle in animals after transference across the equator, with further observations on the incidence of the breeding seasons and the factors controlling sexual periodicity. Proc. Royal Soc. London. 122, 413-428.

Martin, G.B., and Scaramuzzi, R.J. 1983. The induction of oestrus and ovulation in seasonally anovular ewes by exposure to rams. J. Steroid Biochem. 19, 869-875.

Martin, G.B., Oldham, C.M., Cognie, Y., and Pearce, D.T. 1986. The physiological responses of anovulatory ewes to the introduction of rams - a review. Livest. Prod. Sci. $15,219-247$.

McKenzie, F.F., and Terrill, C.E. 1937. Estrus, ovulation, and related phenomena in the ewe. 264. Mo. Agr. Exp. Sta. Bull.

McLeod, B.J., Haresign, W. and Lamming, G.E. 1982. Response of seasonally anoestrous ewes to small-dose multiple injections of GnRH with and without progesterone pretreatment. J. Reprod. Fert. 65, 223-230.

McLeod, B.J., Haresign, W., and Lamming, G.E. 1982. The induction of ovulation and luteal function in seasonally anoestrous ewes treated with small-dose multiple injections of GnRH. J. Reprod. Fert. 215-221.

McNatty, K.P., Ball, K., Gibb, M., Hudson, N., and Thurley, D.C. 1982. Induction of cyclic ovarian activity in seasonally anoestrous ewes with exogenous GnRH. J. Reprod. Fert. 64, 93-96. 
Moss, G.E., Adams, T.E., Niswender, G.D., and Nett, T.M. 1980. Effects of parturition and suckling on concentrations of pituitary gonadotropins, hypothalamic GnRH and pituitary responsiveness to GnRH in ewes. J. Anim. Sci. 50, 496-502.

Newton, J.E., and Betts, J.E. 1972. A comparison between the effect of various photoperiods on the reproductive performance of Scotch half-bred ewes. J. Agric. Sci., Cambridge. 78, 425-433.

Notter, D.R. 1992. Genetic improvement of out-of-season breeding through selection. p 55-81. Iowa State University, Iowa State University Extension, Out of season breeding symposium.

O'Callaghan, D., Karsch, F.J., Boland, M.P., and Roche, J.F. 1991. What photoperiodic signal is provided by a continuous-release melatonin implant? Biol. Reprod. 45, 927933.

Oldham, C.M., and Martin, G.B. 1978. Stimulation of seasonally anovular Merino ewes and rams II: Premature regression of ram-induced corpora lutea. Anim. Reprod. Sci. 1, 291-295.

Oldham, C.M., Pearce, D.T., and Gray, S.J. 1985. Progesterone priming and age of ewe affect the life-span of corpora lutea induced in the seasonally anovulatory Merino ewe by the 'ram-effect.' J. Reprod. Fert. 75, 29-33.

Oldham, C.M. and Fisher, J. 1992. Utilizing the ram effect. p 33-54. Iowa State University, Iowa State University Extension, Out of season breeding symposium.

Pearce, D.T., Martin, G.B., and Oldham, C.M. 1985. Corpora lutea with a short lifespan induced by rams in seasonally anovulatory ewes are prevented by progesterone delaying the preovulatory surge of LH. J. Reprod. Fert. 75, 79-84.

Pelletier, J and Almeida, G. 1987. Short light cycles induce persistent reproductive activity in Ile-de-France rams. J. Reprod. Fert. Suppl. 34, 215-226.

Pope, W.F., McClure, K.E., Hogue, D.E., and Day, M.L. 1989. Effect of season and lactation on postpartum fertility of Polypay, Dorset, St. Croix, and Targhee ewes. J. Anim. Sci. 67, 1167-1174.

Quirke, J.F., Stabenfeldt, G.H., and Bradford, G.E. 1985. Onset of puberty and duration of the breeding season in Suffolk, Rambouillet, Finnish Landrace, Dorset, and FinnDorset ewe lambs. J. Anim. Sci. 60, 1463-1471.

Quirke, J.F., Stabenfeldt, G.H., and Bradford, G.E. 1988. Year and season effects on oestrus and ovarian activity in ewes of different breeds and crosses. Anim. Reprod. Sci. $16,39-52$. 
Restall, B.J., and Radford, H.M. 1974. The induction of reproductive activity in lactating ewes with gonadotropin-releasing hormone (GnRH). J Reprod. Fert. 36, 475476.

Rhind, S.M., Robinson, J.J., Chesworth, J.M., and Phillippo, M. 1980. Effects of season, lactation and plane of nutrition on the reproductive performance and associated plasma LH and progesterone profiles in hormonally treated ewes. J. Reprod. Fert. 58, 127-137.

Rhind, S.M., McMillen, S., McKelvey, W.A.C., Rodriguez-Herrejon, F.F., and McNeilly, A.S. 1989. Effect of the body condition of ewes on the secretion of LH and FSH and the pituitary response to gonadotrophin-releasing hormone. J. Endocrinol. 120, 497-502.

Robinson, T.J. 1950. The control of fertility in sheep. I. Hormonal therapy in the induction of pregnancy in the anestrous ewe. J. Agric. Sci. 40, 265-307.

Robinson, T.J. 1955. Endocrine relationships in the induction of oestrus and ovulation in the anestrous ewe. J. Agric. Sci. 37-43.

Robinson, J.E. 1990. Endogenous annual rhythms of luteinizing hormone secretion in the ewe and their entrainment by photoperiod. Prog. Clin. Biol. Res. 342, 653-658.

Ronayne, E, Jordan, B, Quirke, J.F., and Roche, J.F. 1989. The effect of frequency of administration of melatonin on the time of onset of the breeding season in anoestrous ewes. Anim. Reprod. Sci. 18, 13-24.

Scaramuzzi, R.J., Tillson, S.A., Thorneycroft, I.H., and Caldwell, B.V. 1971. Action of exogenous progesterone and estrogen on behavioural estrus and luteinizing hormone levels in the ovariectomized ewe. Endo. 88, 1184-1189.

Schinckel, P.G. 1954. The effect of the presence of the ram on the ovarian activity of the ewe. Aust. J. Agric. Res. 5, 465-469.

Southee, J.A., Hunter, MG., Law, A.S., and Haresign, W. 1988. Effect of hysterectomy on the short life-cycle corpus luteum produced after GnRH-induced ovulation in the anoestrous ewe. J. Reprod. Fert. 84, 149-155.

Stellflug, J.N., Fitzgerald, J.A., Parker, C.F., and Bolt, D. 1988. Influence of concentration, duration, and route of administration of melatonin on reproductive performance of spring-mated Polypay and Polypay-cross ewes. J. Anim. Sci. 66, 18551863.

Stevens, R.D., Seguin, B.E., and Momont, H.W. 1993. Simultaneous injection of PGF2alpha and GnRH into diestrus dairy cows delays return to estrus. Therio. 39, 373380. 
Stevenson, J.S., and Call, E.P. 1988. Fertility of postpartum dairy cows after administration of gonadotropin releasing hormone and prostaglandin F2alpha: a field trial. J. Dairy Sci. 71, 1926-1933.

Stevenson, J.S., Call, E.P., and Scoby, R.K. 1990. Double insemination and gonadotropin-releasing hormone treatment of repeat-breeding dairy cattle. J. Dairy Sci. 73, 1766-1772.

Thatcher, W.W., Drost, M., and Savio, J.D., Macmillan, K.L., Entwistle, K.W., Schmitt, E.J., De La Sota, R.L., and Morris, G.R. 1993. New clinical uses of GnRH and its analogues in cattle. Anim. Reprod. Sci. 33, 27-49.

Underwood, E.J., Shier, F.L., and Davenport, N.J. 1944. The breeding season of Merino, crossbred, and British breed ewes in the agricultural districts. J. Agric. 11, 135143.

Waller, S.L., Hudgens, R.E., Diekman, M.A., and Moss, G.E. 1988. Effect of melatonin on induction of estrous cycles in anestrous ewes. J. Anim. Sci. 66, 459-463.

Watson-Whitmyre, M., and Stetson, M.H. 1983. Stimulation of peak melatonin release restores sensitivity to evening melatonin injections in pinealectomized hamsters. Endocrin. 112, 763-765.

Wheaton, J.E., Pohl, H.A., and Windels, H.F. 1990. Effects of melatonin and progesterone administered to ewes in spring and summer. J. Anim. Sci. 68, 923-930.

Whisnant, C.S. and Inskeep, E.K. 1992. Biological aspects of out-of-season breeding in the ewe. p. 1-24. Iowa State University, Iowa State University Extension, Out of season breeding symposium.

Whiteman, J.V., Zollinger, W.A., Thrift, F.A., and Gould, M.B. 1972. Postpartum mating performance of ewes involved in a twice-yearly lambing program. J. Anim. Sci. $35,836-842$.

Williams, G. L., Kotwica, J., Slanger, W.D., Olson, D.K., Tilton, J.E., and Johnson, L.J. 1982. Effect of suckling on pituitary responsiveness to gonadotropin-releasing hormone throughout the early postpartum period of beef cows. J. Anim. Sci. 54, 594-602.

Williams, L.M., and Helliwell, R.J.A. 1993. Melatonin and seasonality in the sheep. Anim. Reprod. Sci. 33, 159-182.

Wodzicka-Tomaszewska, M., Hutchinson, J.C.D., and Bennett, J.W. 1967. Control of the annual rhythm of breeding in ewes: effect of an equatorial daylength with reversed thermal season. J. Agric. Sci. 68, 61-67. 
Vita

Name

Katherine Mead Jordan

Family

Gail Mooney Webb, mother James William Jordan, Ph.D., father Anna Jordan Wills, sister

Date of Birth

May $1^{\text {st }}, 1982$

Place of Birth

Farmville, Virginia, U.S.A.

Schools Attended

Prince Edward County Public Schools

1987-2000

Southside Virginia Governor's School

for Global Economics and Technology

1998-2000

Virginia Polytechnic Institute and

State University, B.S.

2000-2003

West Virginia University

2003-2005 